\title{
Nutritional aspects applied to grazing cattle in the tropics: a review based on Brazilian results
}

\section{Aspectos nutricionais aplicados a bovinos em pastejo nos trópicos: uma revisão baseada em resultados obtidos no Brasil}

\author{
Edenio Detmann ${ }^{1 *}$; Mário Fonseca Paulino ${ }^{1}$; \\ Sebastião de Campos Valadares Filho²; Pekka Huhtanen ${ }^{3}$
}

\begin{abstract}
This review presents and discusses the nutritional and physiological aspects of cattle production under grazing in the tropics. The critical evaluations were based on Brazilian experimental results as well as on basic literature concerning ruminant nutrition. Several associations between the characteristics of the grazed forage, the composition of the supplements and animal and microbial requirements were established. The adopted approach was divided according to two different climatic seasons observed in the tropics: dry and rainy seasons. During the dry season, the main nutritional constraints on animal performance are associated with inherent requirements of the rumen fibrolytic microorganisms. An overall deficiency of nitrogenous compounds is observed in the forage, which compromises forage intake and digestibility. Supplementation with nitrogenous compounds must be a priority in this season to increase forage intake and energy extraction from forage fiber. However, during the rainy season, no constraints on microbial growth are observed. The usual pasture composition presents an unbalanced and high ratio of energy to protein when compared to animal requirements. In such cases, protein supplementation is needed to equilibrate the basal diet and improve the utilization of metabolizable energy and protein.
\end{abstract}

Key words: Cattle production, supplementation, ruminant metabolism, tropical forages

\section{Resumo}

A presente revisão baseia-se na apresentação e discussão dos aspectos nutricionais da produção de bovinos em pastejo nos trópicos. As avaliações críticas foram calcadas em resultados experimentais obtidos no Brasil bem como na literatura básica relacionada à nutrição de ruminantes. Diversas associações entre características da forragem pastejada, a composição dos suplementos e os requerimentos microbianos e dos animais foram estabelecidas. A abordagem adotada foi organizada de acordo com duas diferentes estações climáticas observadas em regiões tropicais: estação seca e estação chuvosa. Durante a estação seca as principais limitações nutricionais estão associadas a deficiências relacionadas aos requerimentos dos microrganismos fibrolíticos do rúmen. Deficiência global de compostos nitrogenados é verificada na forragem, o que compromete o consumo e a digestão da forragem. A suplementação com compostos nitrogenados deve ser prioritária nesta estação para se incrementar o consumo de forragem e a extração de energia a partir da fibra. Contudo, durante a estação chuvosa não são observadas limitações inerentes

\footnotetext{
${ }^{1}$ Associates Profs., Department of Animal Science, Universidade Federal de Viçosa, UFV, Viçosa, MG, Brazil. E-mail: detmann@ ufv.br; mpaulino@ufv.br

${ }^{2}$ Prof., Department of Animal Science, UFV, Universidade Federal de Viçosa, Viçosa, MG, Brazil. E-mail: scvfilho@ufv.br

${ }^{3}$ Prof., Department of Agricultural Research for Northern Sweden, Swedish University of Agricultural Sciences, Umeå, Sweden. E-mail: pekka.huhtanen@slu.se

* Author for correspondence
} 
ao crescimento microbiano. A composição da forragem revela, em media, uma elevada relação energia:proteína em comparação à mesma relação nos requerimentos dos animais. Nestes casos, a suplementação proteica se faz necessária para equilibrar a dieta basal e melhorar a utilização da energia metabolizável e da proteína metabolizável.

Palavras-chave: Forragens tropicais, metabolismo ruminal, produção bovina, suplementação

\section{Introduction}

The production of ruminant animals under grazing must be understood as a complex and interactive system whose efficiency is determined by three different types of resources: basal nutritional resources, supplemental nutritional resources, and animal genetic resources. The final output of the system is represented by the quantity and quality of the products and by economic and environmental efficiencies of production. Because the system is interactive, production must be understood beyond the single sum of the different resources. Such affirmation indicates that the individual response of each resource is dependent upon how it affects the others and, at same time, how its own efficiency is affected by the other resources. Therefore, the planned utilization of each productive resource must consider how that resource influences and is influenced by the other components of the production system (DETMANN; PAULINO; VALADARES FILHO, 2010).

Briefly, genetic resources are responsible for providing animals that are adapted to the conditions of production and present an adequate potential to convert the basal and supplemental nutritional resources into animal products. If this prerequisite cannot be assured, productive efficiency will be low, and any investment in nutrition technologies will not be profitable.

The basal nutritional resources consist of any type of resource available in the production system that is able to provide nutrients and nutritional attributes without the introduction of external resources, such as concentrate or minerals. The latter are exotic to the production system and must be viewed as supplemental nutritional resources
(PAULINO et al., 2008; DETMANN, 2010).

The pasture is the main basal nutritional resource for animal production in the tropics. Specifically, the potentially digestible fraction of organic matter (whose main component is the potentially digestible fraction of neutral detergent fiber) represents the most important substrate for the biosynthesis of ruminant products (DETMANN; PAULINO; VALADARES FILHO, 2008; PAULINO et al., 2008; DETMANN, 2010).

The forage under grazing is a basal nutritional resource of great complexity because its ability to supply substrates for animal production varies qualitatively and quantitatively throughout the year according to the influence of climatic variables, such as rainfall, temperature and solar radiation. Nevertheless, animal production must be continuous throughout the year, which demands nutritional technologies and resources to overcome the deficiencies of the pasture (DETMANN; PAULINO; VALADARES FILHO, 2010).

The joint action of basal and supplemental resources on animal production was previously defined as an interactive effect. In this context, the application of nutritional technologies to systems in which animals are kept under grazing must be supported by understanding and exploring the interaction between forage and supplements with the aim of optimizing the economic and productive variables of the system (DETMANN; PAULINO; VALADARES FILHO, 2008; PAULINO et al., 2008).

In the majority of the feed evaluation systems the digestibilities of the feeds are supposed to be additive to each other, irrespective to of feeding level or components of the diet. This approach assumes that 
there are no interactions in the digestibility or in the efficiency of utilization of the dietary energy caused by mixing the components of a diet (HUHTANEN, 1991). This situation is unlikely to be observed in supplemented grazing cattle in the tropics because the interactive effects are a component of the production system. Considering grazing animals, the interactive effect is negative when the input of supplements gives the diet a lower feeding value (digestibility plus intake) compared to the sum of the individual resources (forage plus supplement). By contrast, an interactive effect is positive when the feeding value of the diet is greater than the sum of the feeding values of the individual resources.

Therefore, a grazing cattle production system is optimized when it is managed to maximize the occurrence of positive interactive effects and/or to minimize the negative interactive effects between basal and supplemental nutritional resources.

\section{Nutritional planning for grazing cattle}

An optimal supplementation program should be based on the utilization of supplements according to two different theoretical nutritional phases. In the first phase, the utilization of basal resources must be maximized, which allows production costs to be minimized. In the second phase, supplements are added to the system to supply the animal requirements for reaching the planned production targets (e.g., age at first calving, age at slaughtering) (Figure 1).

Figure 1. Theoretical description of a production system that is based on the utilization of supplemental nutritional resources.

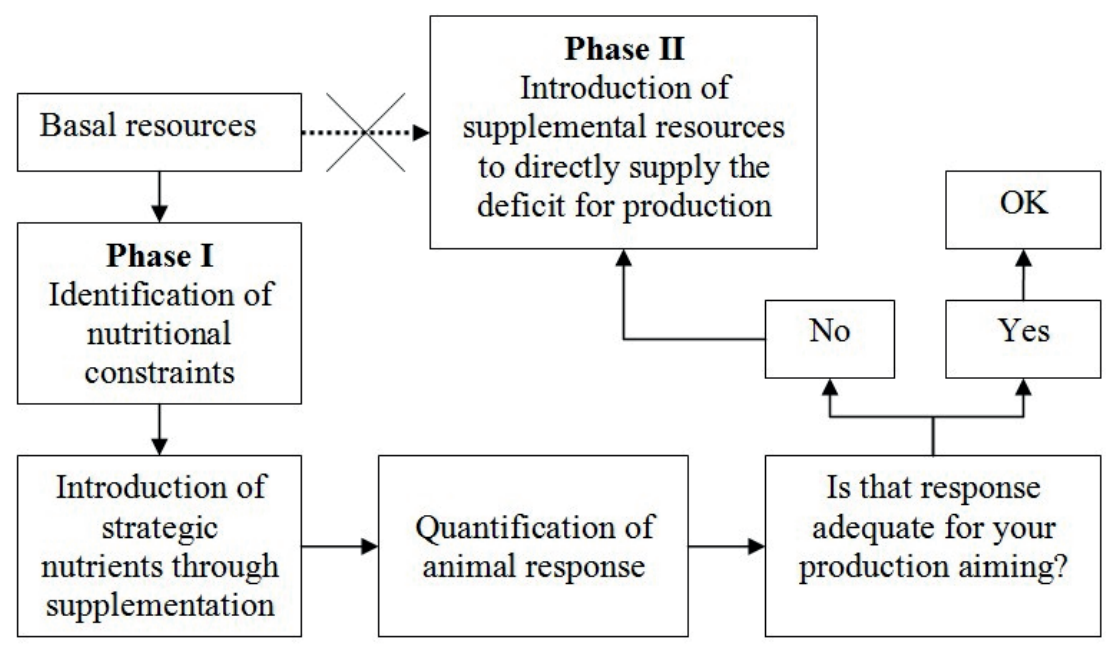

Source: Detmann, Paulino and Valadares Filho (2010).

Two points must be emphasized with regard to the second nutritional phase. First, the second phase must be planned by considering the production targets and the potential production that can be obtained after the application of the first phase of supplementation. The potential for production of basal resources after correcting the main nutritional constraint(s) is the starting point for calculating the type and amount of nutrients to be supplied in the second phase (Figure 1). Second, the second phase never must be applied before considering the first phase because the indiscriminate use of supplemental resources can lead to a decrease in pasture utilization (e.g., non-optimized pasture intake). In some cases, an apparent improvement in production could occur, but the interaction 
between basal and nutritional resources would not be optimized and feed and economic losses would result (DETMANN, 2010).

The first phase of supplementation planning is the primary basis for exploring cattle production under grazing and should be understood as much more complex than the second phase because the first phase demands knowledge of nutrition, physiology, and microbiology. The key to understanding the first nutritional phase is identifying the main nutritional constraint(s) of the pasture and then strategically supplying nutrients through the use of supplements (Figure 1).

The potential of a pasture to be transformed into animal products is represented by the potentially digestible fraction of organic matter (whose main component is the potentially digestible fraction of neutral detergent fiber). However, the full utilization of that resource is unachievable because the potentially digestible fractions are theoretical asymptotic concepts whose complete utilization demands an infinite retention time within the gastrointestinal tract (VAN SOEST, 1994).

Under practical conditions, animal production from the basal resources is supported by the participation of potentially digestible fraction on the total organic matter of the forage and by the fractional utilization of this potentially digestible fraction in the gastrointestinal tract. The first phase of nutritional planning aims to increase the fraction of forage that is used by the animal, generating equilibrium between the extraction of nutrients and the maintenance of an appropriate voluntary intake. The feeding value of the diet, mainly the portion coming from available pasture, must be maximized. Therefore, the optimal utilization of basal resources by the animal should be defined as the perfect balance between intake and digestion or ruminal degradation, which means a maximization of the intake of digested compounds. On this theoretical point, the intake of energy extracted from neutral detergent fiber
(NDF) will be maximal, which is a critical factor for animals fed forage-based diets.

\section{Utilization of low-quality tropical forages}

Low-quality forages generally occur on tropical pastures during the dry season. Such forages are low in crude protein (CP) and have an increased concentration of lignin in the cell wall, which implies decreased intake and digestibility. Under these circumstances, several nutritional deficiencies in the basal resources are observed, including energy, protein and minerals.

The intrinsic limitations of low-quality forage are inherent to microbial growth in the rumen. Such forages have a high carbon-to-nitrogen ratio that causes an absolute deficiency of nitrogenous compounds for the synthesis of microbial enzymes, which, in turn, are responsible for the degradation of cell wall compounds of forage (DETMANN et al., 2009).

Mineral deficiencies can negatively affect microbial growth in the rumen (SIEBERT; KENNEDY, 1972; LENG, 1990), but they can easily be avoided by using a simple and adequate mineral supply. Thus, strategic supplementation must be based on nitrogen as the main supplement component when considering the first phase of nutritional planning (Figure 1; DETMANN, 2010).

This statement can be supported by the results obtained by Souza et al. (2010), who supplemented cattle fed low-quality tropical forage (5.2\% CP) with nitrogenous compounds (urea, ammonium sulfate and albumin; 4.5:0.5:1.0) and/ or non-fibrous carbohydrates (NFC). The authors verified that supplementation with nitrogenous compounds increased forage intake, whereas NFC supplementation (energy supplementation) decreased forage intake. Although the nitrogen supplement was almost energy free, the total digestible nutrients (TDN) content in the diet was increased by $56.6 \%$ when nitrogen was supplied 
to the animals. By contrast, the almost complete digestibility of starch (NFC) had no effect on the
TDN content, which seemed to reflect the negative effect on forage intake (Figure 2).

Figure 2. Percentual variation of forage intake (FI), total digestible nutrients level in the diet (TDN) and ruminal production of microbial nitrogen (NMIC) compared to control treatment (without supplementation) in cattle fed lowquality tropical forage and supplemented with nitrogen and/or starch.

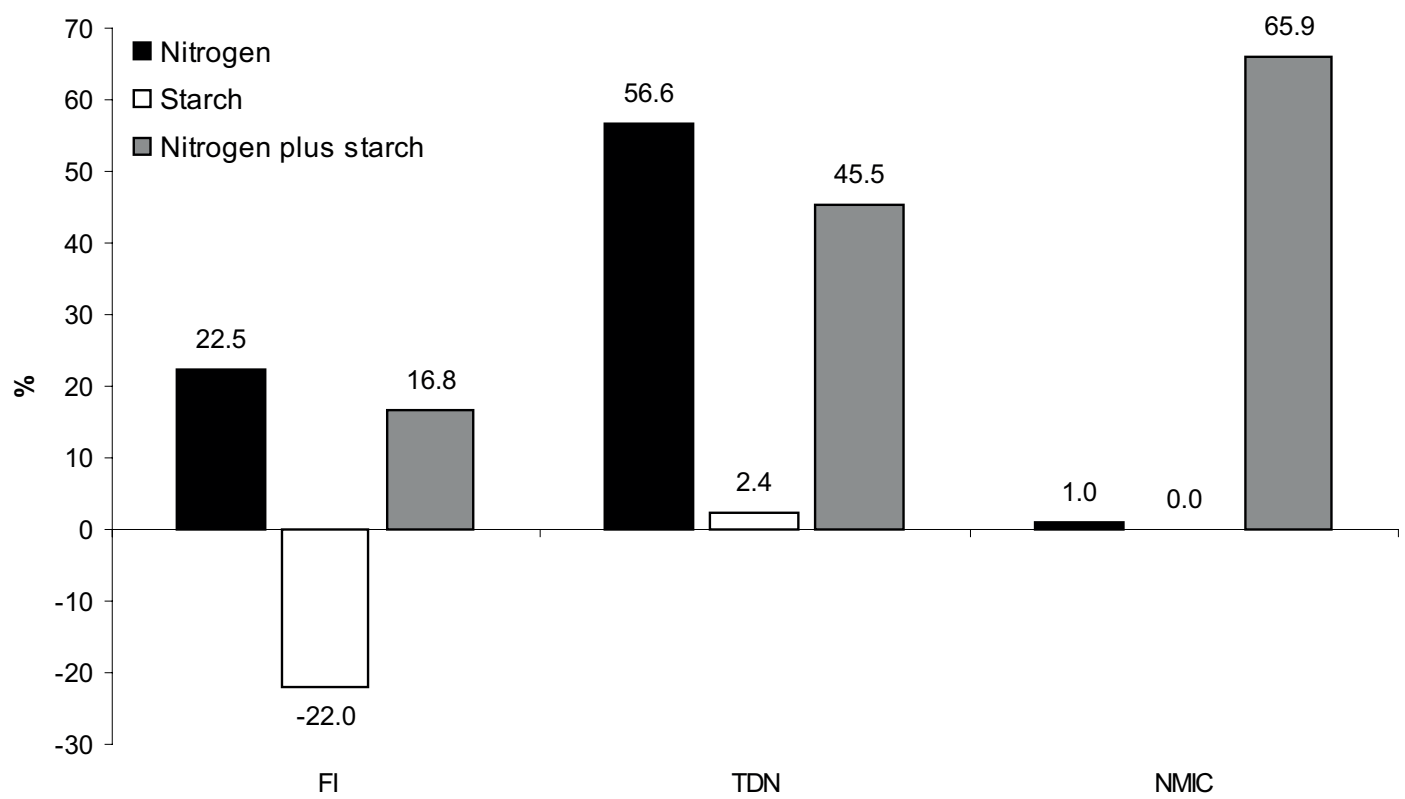

Source: Elaboration of the authors from results of Souza et al. (2010).

The occurrence of a positive effect of nitrogen supplementation is due to the alleviating the overall deficiency of nitrogen in the rumen. This type of deficiency restricts the availability of nitrogen precursors for the synthesis of fibrolytic enzymes (DETMANN et al., 2009; LAZZARINI et al., 2009a; SAMPAIO et al., 2009). Therefore, the interactive effect of nitrogen supplementation leads to the occurrence of and is characterized by sequential responses in which the increased nitrogen availability improves the synthesis of fibrolytic enzymes. In addition, the increased fiber degradation improves the availability of energy for microbial (SOUZA et al., 2010) and animal (LAZZARINI, 2011) growth.

When forage is of low quality, supplementation with rapidly degradable carbohydrates alone does not create positive nutritional or productive effects. The NFC supply can actually increase the competition between fibrolytic and non-fibrolytic microbial species (EL-SHAZLY; DEHORITY; JOHSON, 1961; MOULD; ØRSKOV; MANN, 1983; COSTA et al., 2009; CARVALHO et al., 2011). In addition, because there is not enough nitrogen for adequate enzyme synthesis, the increase in NFC availability can increase the occurrence of energy spilling reactions in the non-fibrolytic microbial species, which will further decrease the efficiency of microbial growth (STROBEL; RUSSELL, 1986; SOUZA et al., 2010).

Given that fibrolytic microorganisms use the rumen ammonia nitrogen (RAN) as their preferential nitrogen source for growth (RUSSELL, 2002), the utilization of fiber in the rumen can be described by the following scheme (DETMANN et al., 2009):

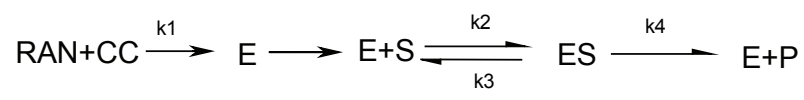

where RAN is the rumen ammonia nitrogen concentration; $\mathrm{CC}$ is the availability of carbon 
chains in the rumen that can be used for amino acid synthesis by microorganisms; $\mathrm{k} 1$ is the constant related to the synthesis of fibrolytic enzymes; E is the enzyme; $\mathrm{S}$ is the substrate (NDF); ES is the enzyme-substrate complex; $\mathrm{P}$ is the product (e.g., volatile fatty acids); and $\mathrm{k} 2, \mathrm{k} 3$, and $\mathrm{k} 4$ are the constants associated with the rates of the chemical transformations on substrate.

In this way, the nitrogen concentration represents a limiting step ( $\mathrm{k} 1$ constant) for the synthesis of enzymes involved in the degradation of fiber of low-quality forages (DETMANN et al., 2009).

The effects of nitrogen supplementation can be directly observed by evaluating the effectively degraded fraction of NDF (EDF) because this fraction reflects the intensity of microbial action on low-quality nutritional resources. A minimal concentration of $8 \mathrm{mg}$ RAN/dL of rumen fluid must be provided through supplementation to provide fibrolytic microorganisms the complete capacity to degrade the fiber of low-quality forage (Figure 3 ).

Figure 3. Relationship between the effectively degraded fraction of neutral detergent fiber (EDF, $\hat{Y}=-35.4390+$ $10.323 \times X, \forall X \leq 8.0048, \hat{Y}=47.1940, \forall X>8.0048, R^{2}=0.9124 ; \mathrm{n}=50$ ), the NDF intake (NDFI, $\hat{Y}=8.6387+$ $0.8353 \times \mathrm{X}-0.027525 \times \mathrm{X}^{2}, \mathrm{R}^{2}=0.5087 ; \mathrm{n}=50$ ) and rumen ammonia nitrogen concentration (RAN) in cattle fed low-quality tropical forage and supplemented with nitrogenous compounds.

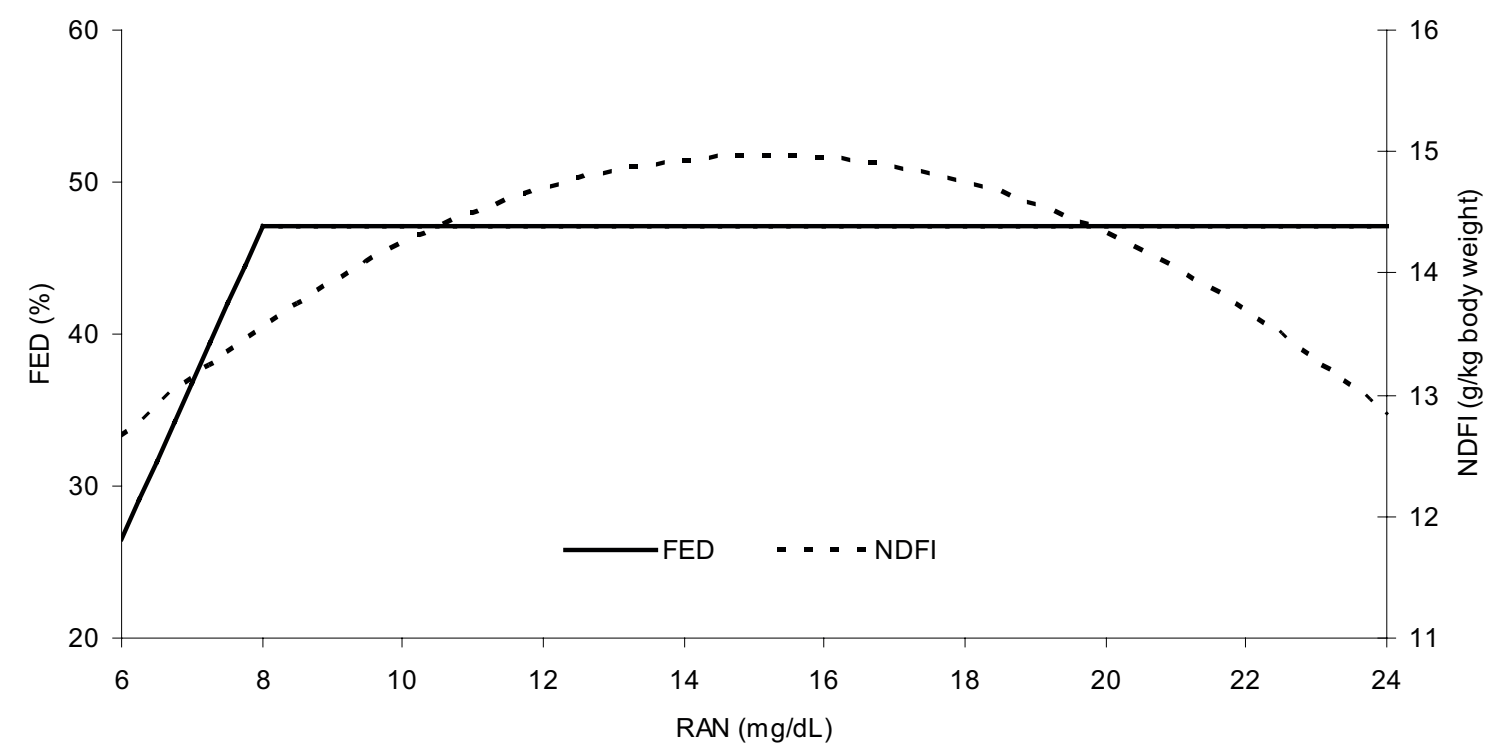

Source: Elaboration of the authors from results of Detmann et al. (2009).

When there is an ammonia deficiency $(\mathrm{RAN}<$ $8 \mathrm{mg} / \mathrm{dL})$, the EDF estimates become lower than when ammonia is not limiting. In these cases, some of the energy of the forage will not be extracted and will persist in a latent form. Such latent energy represents a possible source of low-cost energy for animal production that is unavailable due to the restriction of nitrogenous precursors for the synthesis of microbial enzymes. This argument emphasizes that nitrogen supplements play a major role in cattle fed low-quality tropical forages (PAULINO et al., 2008; DETMANN; PAULINO; VALDARES FILHO, 2010).

This pattern emphasizes that fiber utilization in the rumen is a second-order process. The degradation is determined by both the inherent characteristics of the substrate (forage) and the availability of microbial enzymatic systems. 
Therefore, when RAN concentrations are restricted (Figure 3), the dynamics of fiber degradation occur with a predominance of zero-order reactions, which are characterized by some limitation on enzyme availability (MERTENS, 1993). Under these circumstances, positive responses in fiber degradation will be observed with a supplementation program that allows the RAN concentration to be increased up to $8 \mathrm{mg} / \mathrm{dL}$ (DETMANN et al., 2009; FIGUEIRAS et al., 2010). However, the plateau in EDF estimates observed when the RAN concentration becomes greater than $8 \mathrm{mg} / \mathrm{dL}$ seems to indicate that nitrogen supplementation does not affect fiber degradation (Figure 3). Therefore, the ruminal degradation must be described by firstorder reactions whose occurrence is mainly defined by the characteristics of the substrate (MERTENS, 1993; DETMANN; PAULINO; VALADARES FILHO, 2008; DETMANN et al., 2009).

However, the increase in ruminal degradation of NDF with improved RAN availability (Figure 3) directly indicates only an increase in digestibility, with no explicit effect on forage intake.

The intake of low-quality forage is closely associated with the rumen fill effect of insoluble fiber (DETMANN, 2010). If the rumen fill effect prevails, the intake of new feed (a new input of forage) would be predominately determined by the output of resident material in the rumen (WALDO; SMITH; COX, 1972; DETMANN, 2010). The improvement of the degradation rate enhances the disappearance of potentially digestible NDF (pdNDF) from the rumen (COSTA et al., 2008; DETMANN et al., 2011); however, a part of the pdNDF and the indigestible NDF (iNDF) can be removed from the rumen only by passage.

The overall effect of nitrogen supplementation on the utilization of low-quality forage is defined by the inter-relationship of degradation and transit in the rumen. The fibrous particles that enter the rumen remain in a dorsal position. As the pdNDF is degraded, there is an increase in the relative content of iNDF in the fiber particle. The iNDF fraction is normally denser, and so the fiber particles tend to migrate to ventral positions where the escape probability is greater (ALLEN, 1996). Therefore, rumen transit is indirectly improved by an increase in the rate of fiber degradation, and such an effect is observed when supplemental nitrogen is given to animals fed low-quality tropical forages (LAZZARINI et al., 2009a; SAMPAIO et al., 2009; SOUZA et al., 2010).

Some observations in the tropics indicate that maximization of rumen transit and fiber intake of low-quality tropical forages can be achieved if a RAN concentration of $15 \mathrm{mg} / \mathrm{dL}$ is implemented by supplementation (Figure 3; DETMANN et al., 2009).

The divergence between RAN concentrations for optimizing NDF degradation and intake (Figure 3) contradicts the assumption that intake of low-quality forages is defined only by physical constraints because, if this assumption were true, maximal NDF degradation would be coincident with maximal NDF intake. A similar pattern was reported by Leng (1990), who suggested concentrations of 10 and 20 $\mathrm{mg}$ RAN/dL to optimize degradation in the rumen and voluntary intake under tropical conditions, respectively.

However, this divergence seems to represent differences in nitrogenous compounds requirements between microorganisms and the host animal (VAN SOEST, 1994). Thus, a RAN concentration of 8 $\mathrm{mg} / \mathrm{dL}$ appears to be sufficient to meet the nitrogen demand of fibrolytic microorganisms, but not to supply nitrogenous compounds to the host animal (DETMANN et al., 2009).

The maximization of microbial nitrogen production in the rumen, the main source of metabolizable protein (MP) for an animal fed a forage-based diet, is also obtained with a RAN concentration of approximately $15 \mathrm{mg} / \mathrm{dL}$ (DETMANN et al., 2009). Although considering the maximization of energy extraction from the 
fiber, the animal continues to present stimulus on voluntary intake with nitrogen supplementation (Figure 3). Such increasing in intake is a possible attempt to meet the MP requirements and avoid a marginal deficiency of protein (FORBES, 1995) or to achieve adequate metabolism through some alteration in the ratio of metabolizable energy (ME) to MP (ILLIUS; JESSOP, 1996).

However, the attempt of the animal to supply the requirements for nitrogenous compounds is associated with a harmonic balance between degradation and intake. The increase in intake is related to an increase in passage (DETMANN et al., 2009; SAMPAIO et al., 2009). When passage increases, the time available for microorganisms to act on NDF decreases. If these activities are perfectly coordinated and a constant velocity of enzyme action is considered, the estimated EDF would be lower, which could compromise the availability of energy to the animal. However, this effect was not verified in our experiments (Figure 3).

Therefore, the maximized NDF intake under RAN concentrations greater than that necessary to optimize degradation (Figure 3) seems to constitute a compensatory mechanism to equilibrate the ME:MP ratio. Because there is a direct and positive association between the degradation rate and the RAN concentration (LAZZARINI et al., 2009b; SAMPAIO et al., 2009; DETMANN et al., 2009), the increase in passage can be compensated by greater enzymatic action when the RAN reach values above the optimum value for fiber degradation. This process would lead to stable EDF estimates, and the energy extracted from low-quality NDF would become unchangeable (Figure 3 ). Thus, the increase in intake would imply a higher supply of MP from microbial protein and could result in improved adequacy of the animal metabolism.

This pattern seems to be plausible from the perspective of a multifactorial intake control. Assuming that the ME:MP ratio is one factor that affects intake (ILLUS; JESSOP, 1996), the adjustment of this ratio by the animal, despite optimal fiber degradation, indicates an attempt to minimize "discomfort" (e.g., body heat production from a relative excess energy) and optimize the intake (FORBES, 2003).

In this way, even considering low-quality forage-based diets, the regulation of voluntary intake cannot be solely defined by one type of regulatory mechanism. Physical constraints on intake, such as the NDF rumen fill effect, act in conjunction with physiological and/or metabolic regulatory mechanisms (DETMANN et al., 2003; HUHTANEN; RINNE; NOUSIAINEN, 2007). Therefore, any feed situation should be defined with regard to the predominance of a specific mechanism (in this case, physical regulation). However, even with a non-predominant contribution to the intake regulation, non-physical regulatory mechanisms have some role in the determination of voluntary intake (HUHTANEN, 2002; DETMANN et al., 2003; 2009).

The action of metabolic factors on intake regulation is supported by the decrease in intake that occurs when an excessive ammonia concentration is present in the rumen (Figure 3). That surplus of nitrogen for animal metabolism has several negative effects on voluntary intake, such as ATP deficiency in liver metabolism due to excessive utilization of the urea cycle (VISEK, 1984), increased body heat production (POPPI; MCLENNAN, 1995), and animal indisposition due to excess ammonia in the blood (DETMANN et al., 2007). Accordingly, a RAN concentration of $15 \mathrm{mg} / \mathrm{dL}$ appears to indicate the limit of the first phase of nutritional planning of supplementation (Figure 1).

The parameterization of the first nutritional phase of supplementation (Figure 1) using the RAN concentration is of great relevance from a nutritional perspective. However, the RAN concentration cannot be easily measured at all times. Thus, it seems that parameterization of supplementation based on diet characteristics could more easily 
be applied under farm conditions. In this context, supplementation objectives could be defined as the $\mathrm{CP}$ content in the diet to be established by using supplemental nitrogen.

As previously highlighted, when animals are fed low-quality tropical forages, there is a prominent dependency on microbial activity for adequate energy extraction from fiber and energy for animal metabolism. Under these conditions, a continuous supply of nitrogen for microbial growth in the rumen must be viewed as a strategy for animal survival (VAN SOEST, 1994). Through this mechanism, the animal decreases urinary nitrogen excretion and increases the fraction of nitrogen that is recycled to the rumen (HENNESSY; NOLAN, 1988; RUFINO, 2011).

Therefore, if an animal's diet is nitrogen deficient, part of the consumed nitrogen that would normally be accreted in the animal body would instead be used for recycling and for supporting microbial growth. When nitrogen deficiency becomes more severe, the animal can mobilize tissue to sustain the mass of recycled nitrogen (NRC, 1985; RUFINO, 2011). Such cases will culminate in decreased weight gain or weight loss, respectively.

Under a severe deficiency of nitrogen in diet, the production of microbial nitrogen in the rumen will be greater than nitrogen intake, which reflects a net gain of nitrogen in the rumen through recycling (Figure 4). However, after being absorbed in the intestine, that recycled mass of nitrogen should be recycled again to the rumen, with no improvement in nitrogen accretion in the body.

According to some Brazilian results, a perfect balance between nitrogen intake and the microbial synthesis of nitrogenous compounds in the rumen can be achieved when supplemental nitrogen is provided to increase the dietary CP concentration to $8 \%$ on a DM basis (Figure 4). That CP content is associated with maximal utilization of dietary fiber (LAZZARINI et al., 2009b), which corresponds to the events presented in Figure 3. Thereby, when animals are fed low-quality tropical forage, at least $8 \% \mathrm{CP}$ in the diet is required to sustain microbial growth from dietary nitrogen and minimize the dependency on nitrogen recycling.

The effect of supplementation on the feed value of the pasture can be measured in vivo through the variation in the intake of digested compounds, such as digested DM or NDF. Such an evaluation allows the effects of supplementation on intake and digestion to be considered simultaneously. In that way, a more reliable evaluation is obtained by using digested NDF because a supplement can increase the intake of digested DM (mainly via supplemental NFC) while not necessarily increasing the feed value of the pasture (PAULINO et al., 2008). Thus, supplemental nitrogen should be supplied to increase the CP content of the diet up to $10 \%$ on a DM basis (Figure 5). 
Figure 4. Relative production of microbial nitrogen in the rumen (RNMIC, g microbial N/g N consumed) as a function of crude protein $(\mathrm{CP})$ level in the diet of cattle fed low-quality tropical forage and supplemented with nitrogenous compounds $\left(\hat{\mathrm{Y}}=2.022 \times \mathrm{e}^{(-0.090 \times \mathrm{X})}, \mathrm{s}_{\mathrm{XY}}=0.067, \mathrm{n}=91, \hat{\mathrm{Y}}=1\right.$ when $\left.\mathrm{X} \approx 7.82 \%\right)$.

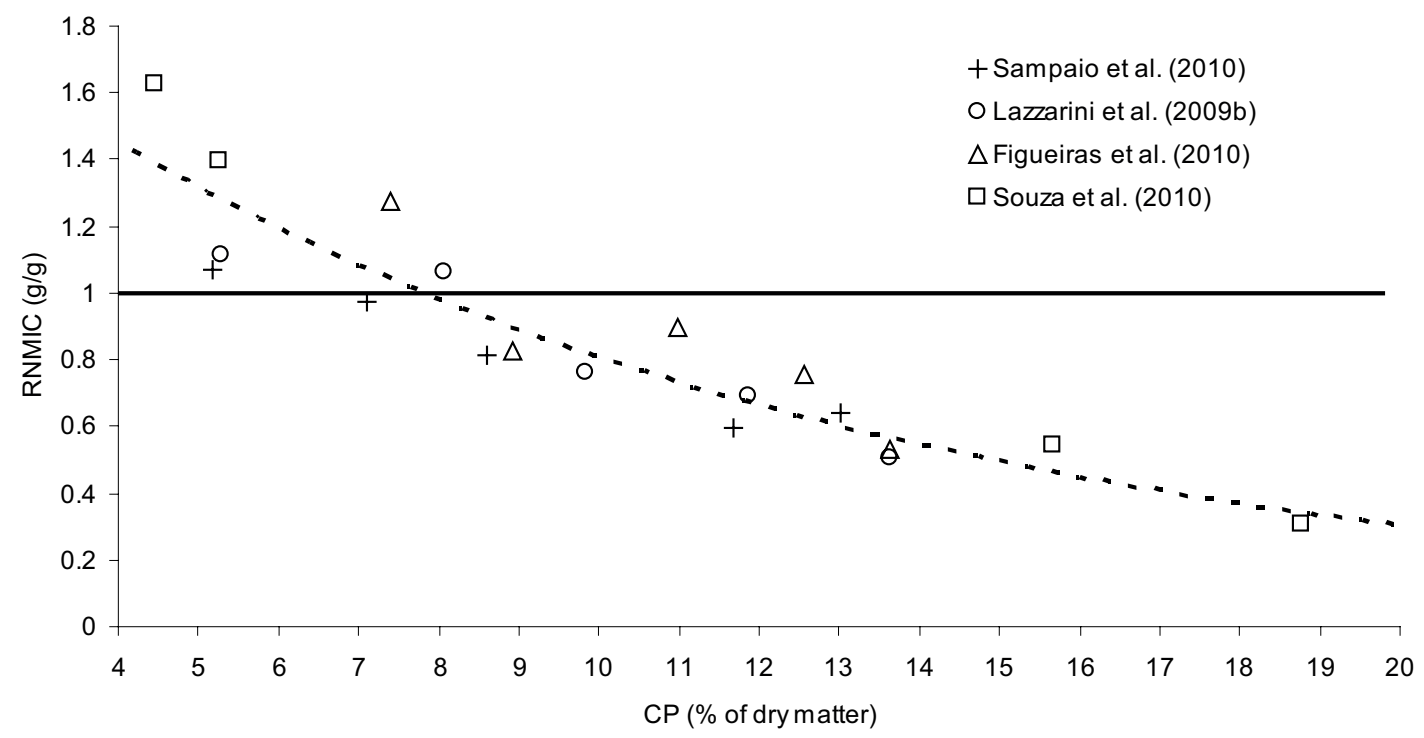

Source: Elaboration of the authors.

Figure 5. Digested NDF intake (DNDFI) as a function of crude protein (CP) level in the diet of cattle fed low-quality tropical forage and supplemented with nitrogenous compounds $(\hat{Y}=1.5575+0.684 \times X, \forall X<10.0311, \hat{Y}=8.4425$ $\forall \mathrm{X} \geq 10.0311, \mathrm{n}=63$ ).

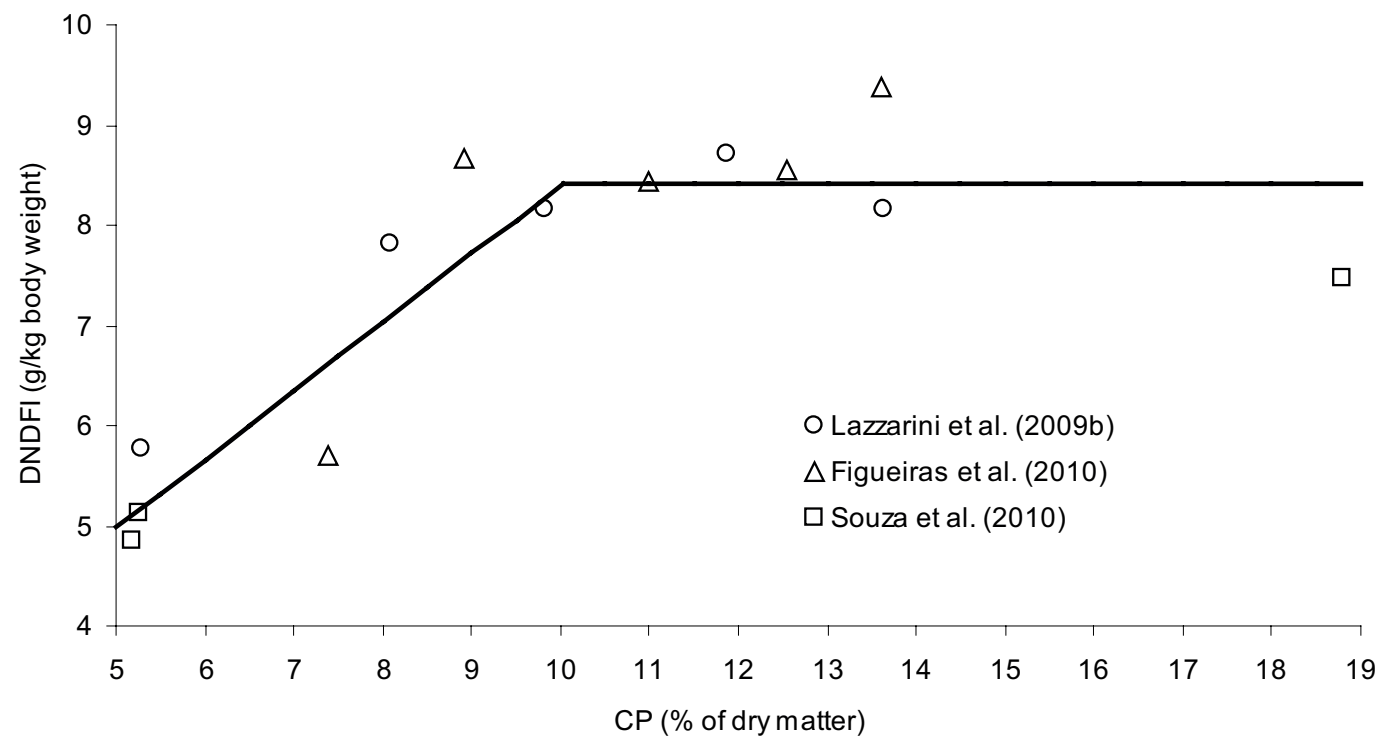

Source: Elaboration of the authors.

The addition of nitrogenous compounds above that limit does not generate additional benefits in terms of the utilization of basal resources (Figure
5). Moreover, this CP content would be associated with maximal energy extraction from low-quality forage (SAMPAIO et al., 2010). Therefore, 
considering the first phase of supplementation planning (Figure 1), any additional increase in the nitrogen supply would cause an accumulation of ammonia in the rumen because the limits of energy extraction from the substrate would be reached and the proportion of diet nitrogen that is assimilated by microorganisms would decrease (DETMANN et al., 2009; DETMANN; PAULINO; VALADARES FILHO, 2010). Such an ammonia surplus could lead to decreased intake, as previously discussed (Figure 3).

Thus, supplementation with nitrogen to increase the CP content of the diet up to $10 \%$ appears to be the limit of the first nutritional phase (Figure 1). Next, the second phase of supplementation should begin, and any new supplemental nitrogen must be given to the animal together with an additional energy source that will support the microbial assimilation of supplemental nitrogen in the rumen and/or improve the utilization of MP.

However, microbial growth in the rumen of animals fed low-quality tropical forages is not yet fully understood. Although there have been improvements in microbial growth on low-quality fiber diets (Detmann et al., 2009), some experiments have demonstrated that nitrogen supplementation does not necessarily cause a significant increase in microbial flow to the intestine (LAZZARINI et al., 2009a; FIGUEIRAS et al., 2010; SOUZA et al., 2010; RUFINO, 2011).

The effects of supplementation with degradable nitrogenous compounds or rapidly degradable carbohydrates on voluntary intake of low-quality forage are thought to be additive. The increase in forage intake caused by nitrogen supplementation is counterbalanced by a decrease in forage intake caused by supplemental carbohydrates. However, the effects of these compounds on microbial nitrogen assimilation in the rumen are thought to be interactive rather than additive (SOUZA et al., 2010). Under these circumstances, the addition of a small amount of rapidly degradable carbohydrates can improve microbial nitrogen assimilation (Figure 2).

Thus, the association of rapidly degradable energy sources with supplemental nitrogen, which has no negative effect on intake, can improve animal performance due to the greater quantity of MP that will arise from increased microbial assimilation of nitrogen (SOUZA et al., 2010; Figure 2). In turn, the supplemental energy from NFC can also improve the MP utilization. However, the exact ratio of nitrogen to energy compounds in the supplements remains to be established.

When rapidly degradable carbohydrates are added to the supplements, some of the parameters concerning optimization of nitrogen availability in the rumen should be modified. The minimal RAN concentration required for optimal fiber degradation $(8 \mathrm{mg} / \mathrm{dL}$, Figure 3 ) appears to be a universal parameter because it is associated with the requirements of fiber-degrading microorganisms. By contrast, the RAN concentration associated with maximal intake $(15 \mathrm{mg} / \mathrm{dL}$; Figure 3$)$ could vary according to the chemical composition of the supplement as well as the diet because this RAN value was established based on the maximal microbial production in the rumen. Adding carbohydrates to the supplements can change the relative participation of microbial species in the ruminal environment. Because RAN requirements vary according to microbial species and substrate (McALLAN; SMITH, 1983; HOOVER, 1986), the RAN concentration associated with maximal voluntary intake can be subject to further alterations.

As previously discussed, most of the constraints for using low-quality pasture are inherent to microbial growth when the first phase of nutritional planning is considered (Figures 1 and 3). However, once these limitations are eliminated, some metabolic aspects become relevant for defining the performance and metabolic efficiency of grazing cattle. Under these circumstances, mechanisms of metabolic integration between energy and protein 
can affect nitrogen accretion in the animal body (LAZZARINI, 2011; Figure 6). Several aspects of that metabolic integration will be discussed in the next section.

Figure 6. Production of microbial nitrogen in the rumen (NMIC) and apparent body balance of nitrogen (NB) in cattle under grazing during dry and rainy seasons (the values are given as differential in $\mathrm{g} / \mathrm{d}$ in relation to the control treatment. The pasture presented 8.24 and $13.49 \% \mathrm{CP}$ in dry and rainy seasons, respectively. N, supplementation with nitrogenous compounds; S, supplementation with starch).

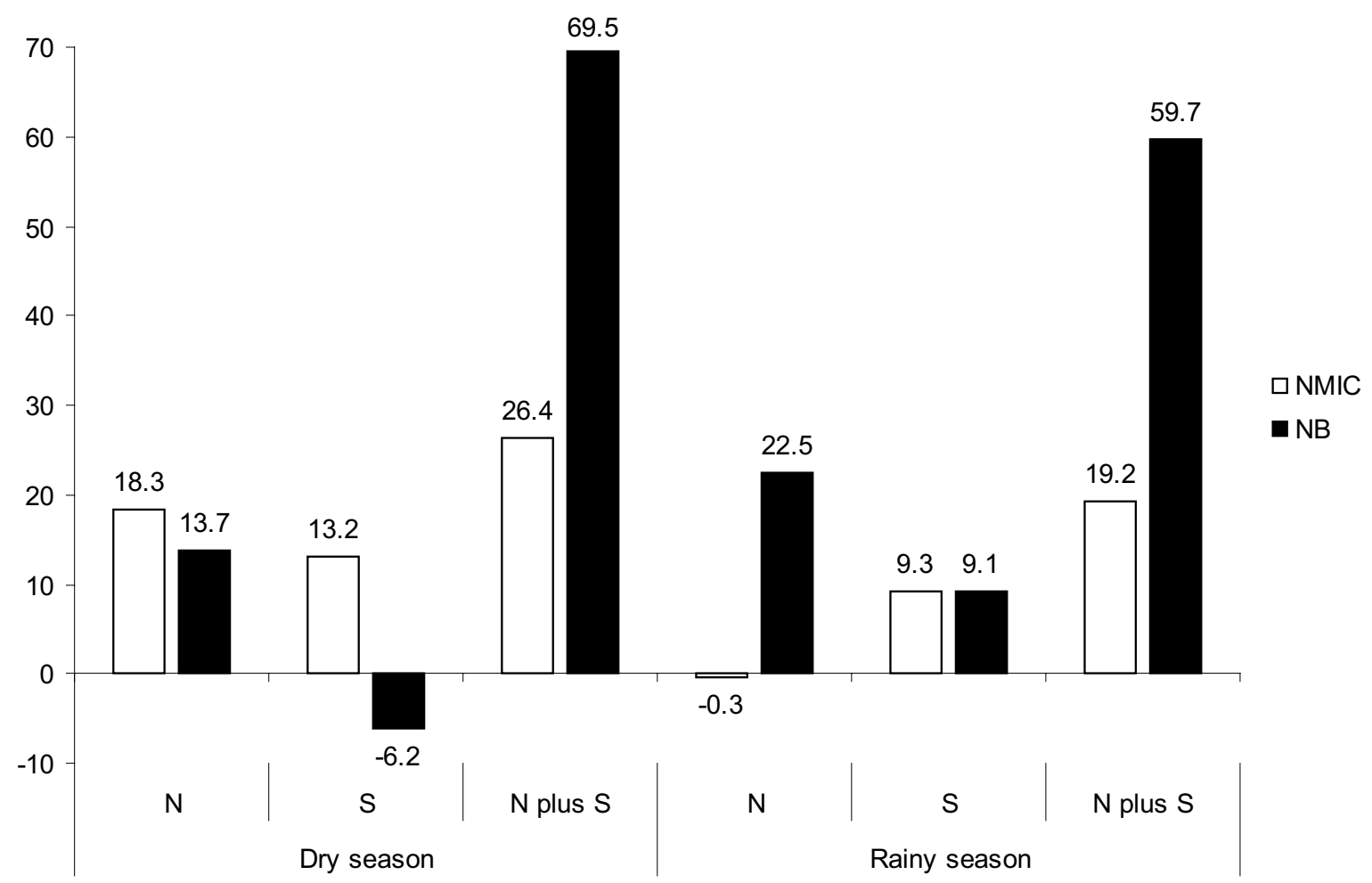

Source: Elaborated of the authors from results of Lazzarini (2011).

\section{Utilization of medium- to high-quality forages}

During the rainy season in the tropics, the available forage undergoes intense growth and is of better quality than the forage available during the dry season. However, despite improved animal performance, the utilization of basal nutritional resources during the rainy season is not thought to be optimized. There is an unused growth potential of approximately $200 \mathrm{~g} / \mathrm{animal} / \mathrm{d}$ that can be achieved by using supplemental resources (PAULINO et al., 2008; DETMANN; PAULINO; VALADARES FILHO, 2010).
Although of lower quality, the chemical composition of the forage available during the dry season is closer to a steady state because there is an almost complete interruption of plant growth. Thus, any variation in the nutritional characteristics of the pasture would be caused by the modification of the forage availability throughout the season. At the beginning of the dry season, the forage availability is greater, which allows the animals to select higher-quality forage. As time passes, the forage availability decreases, and the selection becomes limited, decreasing the quality of the forage selected by the animals. 
However, during the rainy season, the chemical composition of the available forage is not constant because plant growth is intense and can vary throughout the season. In addition, some interactions of the animal with the pasture can cause significant modifications of the quality of the selected forage. From a nutritional point of view, the overall rainy season can be divided into three different phases:

1. the dry-to-rainy transition period, which begins after the dry season when the first rains occur. The temperature and the photoperiod increase as winter ends. Plant regrowth begins, and new leaves emerge. The leaf-to-stem ratio and protein content increase rapidly. The high content of soluble protein in the new leaves can bring some negative effects to animals receiving nitrogen supplements, such as acute diarrhea;

2. the middle rainy season, during which temperature, rainfall and solar radiation become almost constant and adequate for plant growth, despite some short periods without rainfall;

3. the rainy-to-dry transition period, which begins during late summer, when the temperature, photoperiod and rainfall begin to decrease. Normally, plants enter their reproductive stage and their vegetative growth, CP content and leaf-to-stem ratio gradually decrease.

The low nutritional stability of the pasture can modify the nutritional constraints of the forage throughout rainy season, making different supplementation strategies necessary (Figure 1). However, despite the differences in the characteristics of the three phases of the rainy season (Figure 7), the overall nutritional guidelines are similar with regard to several aspects, which will be discussed here.

Figure 7. Diet levels of total digestible nutrients (TDN, \% of dry matter) and crude protein (CP, \% of dry matter) during the different phases of the rainy season (data were taken from 20 experiments, totalizing 95 experimental units).

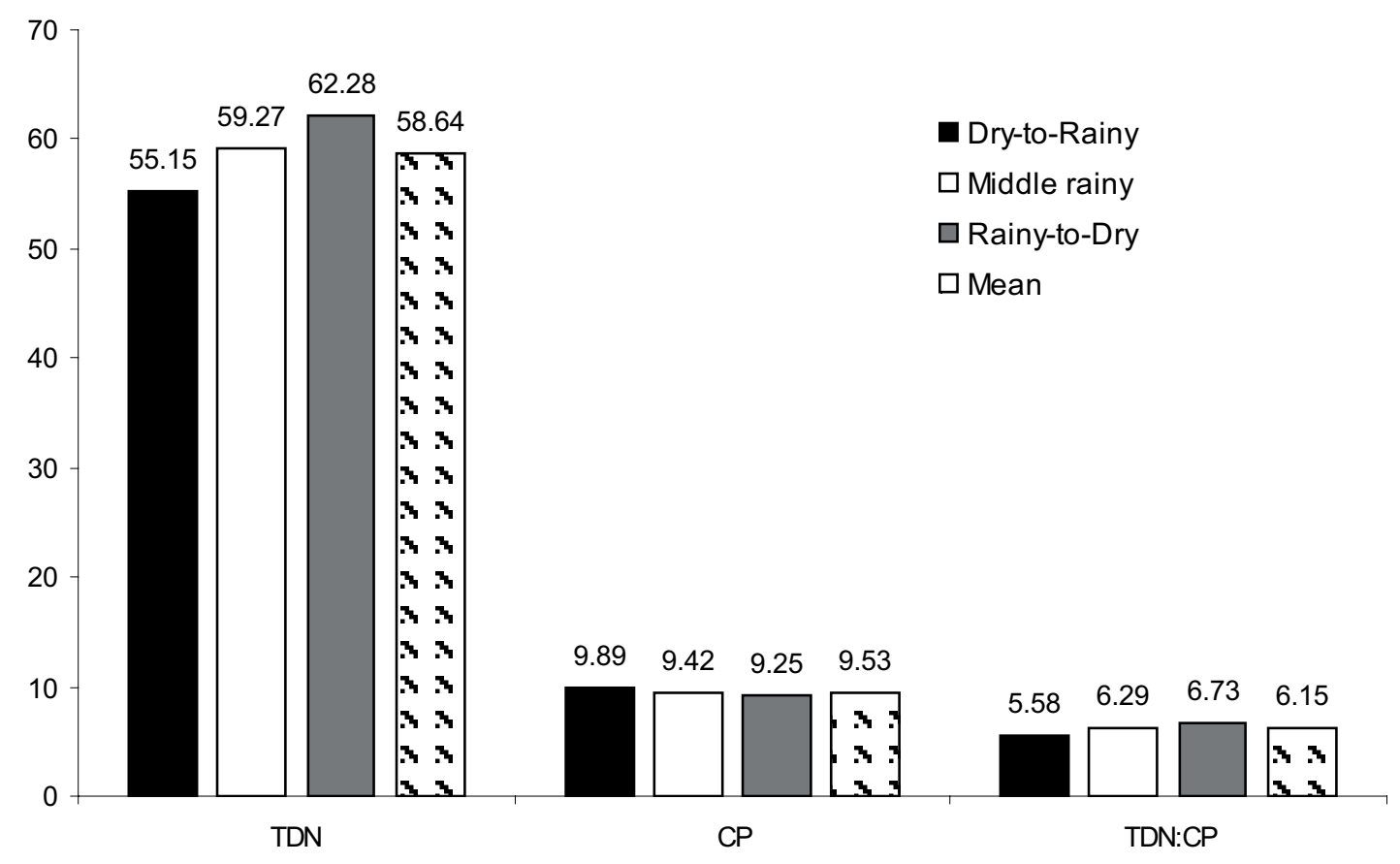

Source: Detmann, Paulino and Valadares Filho (2010). 
Most recommendations for using supplemental resources during the rainy season have been based upon the maxim: "if protein is the priority in the dry season, energy must be the priority during the rainy season". Actually, this maxim is an almost dangerous simplification of reality. There is no scientific support for this statement, which does not take into account the nutritional evaluation of the pasture and the requirements of the animals.

The forage selected by the animals must be evaluated with regard to its capacity for supplying protein and energy. This information must be associated with the nutritional requirements of the animals to identify the main constraint for production (Figure 1).

First, the CP contents of tropical pastures during the rainy season are greater than the minimum needed to sustain microbial growth (Figures 4 and 7). This pattern indicates that the basic limitations for adequate pasture utilization are not those inherent to the constraints on microbial growth. This statement demands a broader understanding of the diet and metabolic balances in the animal body.

The analysis of pastures under continuous grazing management demonstrates that the ratio of TDN to CP is usually greater than that required by the animals (Figures 7 and 8). Thus, the rainy season forage represents a diet with a relative surplus of energy in relation to protein content. Assuming that a balanced ME:MP ratio is a determining factor for maximizing voluntary intake (ILLIUS; JESSOP, 1996; Forbes, 2003), energy supplementation could increase the dietary imbalance with regard to the energy-to-protein ratio. Such a pattern could lead to increased total metabolic "discomfort". In that way, the animal should replace a great amount of forage by a small quantity of supplement (DETMANN et al., 2001; COSTA et al., 2011a) to equilibrate the energy-to-protein ratio attempting to become more comfortable. Those events will culminate in a great substitutive effect on intake, which is not desirable in a production system that should be based on pasture utilization.

Therefore, for most production systems, the primary alteration of the diet via supplements must be based on the addition of dietary protein to adjust the energy-to-protein ratio in the diet (Figure 8). In this case, forage intake and fiber digestibility should not change (COSTA et al., 2011b; 2011c; LAZZARINI, 2011; RUFINO, 2011; BATISTA, 2012). Increased animal performance has been reported by several authors who used protein/ nitrogen supplementation (including urea as a nitrogen source) in animals grazing on mediumto high-quality forages (ZERVOUDAKIS, 2003; ZERVOUDAKIS et al., 2002; 2008; PORTO, 2009).

A characteristic report concerning the positive effects of protein supplementation on animal performance was presented by Porto (2009), who supplemented steers during the rainy season (the forage presented $9.3 \% \mathrm{CP}$ ) with different quantities of supplements but a constant amount of CP. The supplements varied only in the amount of energy they supplied. Overall, supplementation increased weight gain compared to the control without supplementation. However, there was no difference among supplements (Table 1). These results indicate that the protein increased the performance because all of the supplements supplied the same CP amount. Nonetheless, the variation in energy supplied by the supplements did not affect performance, which seems to indicate that energy was not a priority nutrient. 
Figure 8. Ratio of total digestible nutrients (TDN) to crude protein (CP) in the diet of cattle grazing medium- to highquality tropical forage without supplementation [data were taken from 20 experiments, totalizing 95 experimental units. The lines represent the required TDN:CP in the diet considering the nutritional requirements for maintenance plus $1 \mathrm{~kg}$ of daily gain according to Valadares Filho et al. (2010). $\mathrm{B}=$ bull; $\mathrm{S}=$ steer; $\mathrm{F}=$ female].

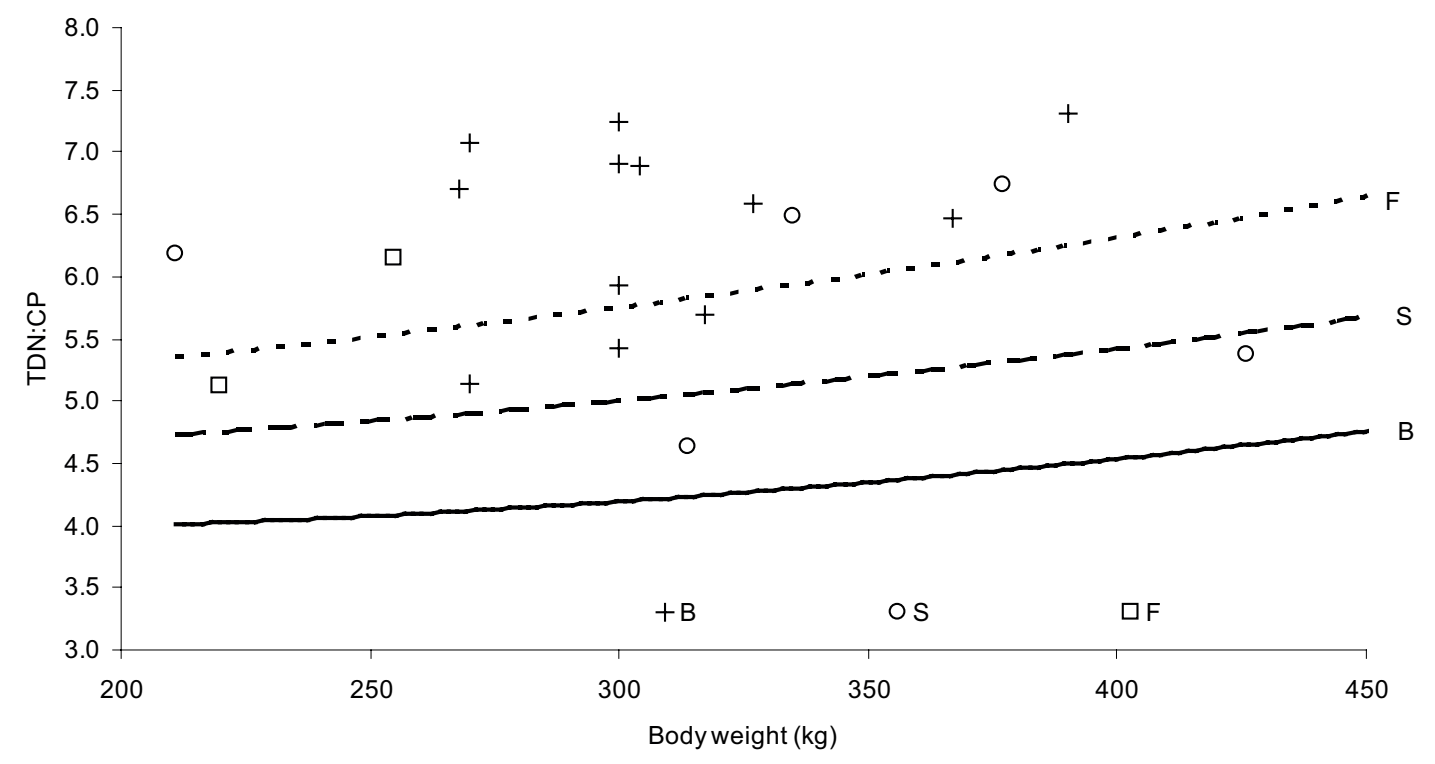

Source: Detmann, Paulino and Valadares Filho (2010).

Table 1. Performance of steers under grazing and supplemented during the rainy season.

\begin{tabular}{lcccc}
\hline \multicolumn{1}{c}{ Item } & \multirow{2}{*}{ Control } & \multicolumn{3}{c}{ Supplement amount $(\mathrm{g} / \mathrm{d})$} \\
\cline { 3 - 5 } & & 750 & 1500 & 2250 \\
\hline CP in supplement (\%) & - & 53.3 & 26.7 & 17.8 \\
CP from supplement (g/d) & - & 400 & 400 & 400 \\
Weight gain (g/d) ${ }^{1}$ & 706 & 952 & 962 & 906 \\
\hline & Composition of the supplement (g/d as fed) & 57 & 58 \\
\hline Mineral mixture & - & 56 & 49 & 49 \\
Urea/Ammonium sulfate (9/1) & - & 47 & 256 & 7 \\
Soybean meal & - & 513 & 569 & 1200 \\
Corn grain & - & 67 & 569 & 936 \\
\hline Wheat bran & - & 67 &
\end{tabular}

${ }^{1}$ There was a significant difference between the control and treatments with supplementation $(\mathrm{P}<0.01)$, but no difference was detected $(\mathrm{P}>0.10)$ among supplemented treatments.

Source: adapted from Porto (2009).

In Brazil, few positive responses of animal performance to energy supplementation have been reported (e.g., RAMALHO, 2006; COSTA, 2007). Nevertheless, those reports have been associated with rotational grazing management and high levels of nitrogen fertilization. Normally, this type of pasture management yields forage with $\mathrm{CP}$ contents greater than $15 \%$ on a DM basis, which can be considered quite different from most beef cattle production systems in which continuous grazing management systems are adopted and low-to-moderate fertilizer levels are used (Figure 
7). When the CP contents of the forage are close to the average values reported here (Figure 7), the responses to energy supplementation are very low and can compromise the economic and productive efficiencies of the production system (e.g., FIGUEIREDO et al., 2011).

An earlier hypothesis for the increment in animal performance upon nitrogen supplementation was based on an increase in MP, which was supplied in two different ways: an increase in microbial nitrogen production caused by supplying rumendegradable protein (RDP) or a direct increase in MP by supplying rumen-undegradable protein (RUP). However, several reports have suggested that the true influence of nitrogen supplementation seems to be supported by some more complex mechanisms that involve metabolic regulation (COSTA et al., 2011b; 2011c; LAZZARINI, 2011; RUFINO, 2011; BATISTA, 2012).

Productive responses to supplementation with RUParenotevident, and similar responses to RUP and RDP supplementation can be found in the literature (e.g., HAFLEY; ANDERSON; KLOPFENSTEIN, 1993; ZERVOUDAKIS et al., 2002). In addition, the increased animal performance or nitrogen balance in response to RDP supplementation cannot be associated with increased microbial nitrogen synthesis (e.g., MARINI; VAN AMBURGH, 2003; PORTO, 2009; RUFINO, 2011; BATISTA, 2012). While some improvement in the amount of microbial nitrogen synthesis can occasionally occur, such an improvement cannot be responsible for all of the observed increase in nitrogen accretion in the animal body (COSTA et al., 2011c; LAZZARINI, 2011; Figure 6).

Most studies have reported that improvements in the weight gain (or body nitrogen balance) of cattle grazing on rainy season pasture and receiving protein supplements are associated with increases in RAN concentration (ZERVOUDAKIS, 2003; MORAES et al., 2006; PAULINO et al., 2006;
ZERVOUDAKIS et al., 2002; 2008; COSTA et al., 2011c; LAZZARINI, 2011).

The pool of RAN is sustained by the degradation of dietary protein and by urea recycling through the saliva and rumen epithelium (VAN SOEST, 1994). Normally, nitrogen recycling is supposed to be more important to sustain the RAN pool only if nitrogen intake is low (HUNTINGTON; ARCHIBEQUE, 2000) because recycling is a mechanism by which microbial requirements can be met when host nitrogen demands are low (VAN SOEST, 1994). If animals are fed diets containing CP contents above that required for microbial growth, it would not be expected a significant participation of nitrogen recycling to sustain the RAN pool, such as that observed where diet CP is below microbial demands (Figure 4).

However, several studies conducted in the tropics have reported a negative balance of nitrogen in the rumen when animals are fed medium- to highquality forages without nitrogen supplementation (COSTA et al., 2011c; LAZZARINI, 2011; RUFINO, 2011; BATISTA, 2012). In this situation, there is a positive relationship between the RAN concentration and the nitrogen balance in the rumen (Figure 9). A negative estimate of rumen balance indicates that the nitrogen outflow is greater than the nitrogen intake, indicating that a significant amount of ruminal nitrogen was provided by recycling even during rainy season. The rumen nitrogen balance becomes positive when the RAN concentrations are greater than $9.7 \mathrm{mg} / \mathrm{dL}$ and is maximized when the RAN exceeds $15.9 \mathrm{mg} / \mathrm{dL}$ (Figure 9).

The urea transferred from the blood to the rumen is readily degraded by ureolytic bacteria that live on the rumen epithelium. Therefore, the urea concentration in the rumen is always lower than that in the blood, which favors a concentration gradient for the transfer of urea to the rumen (VAN SOEST, 1994). Thus, urea transference are sometimes described as a mass action regulated mechanism. 
Figure 9. Relative nitrogen balance in the rumen (RNB, $g \mathrm{~N}$ leaving the rumen $/ \mathrm{g} N$ consumed) as a function of rumen ammonia nitrogen concentration (RAN) in cattle fed medium- to high-quality tropical forages $(\hat{Y}=0.3225 \times[1$ $(9.6501 / \mathrm{X})], \mathrm{s}_{\mathrm{XY}}=0.1841, \mathrm{n}=107$; using the asymptotic confidence interval of the plateau it is obtained that RNB is maximized at $\mathrm{RAN} \geq 15.87 \mathrm{mg} / \mathrm{dL}$ ).

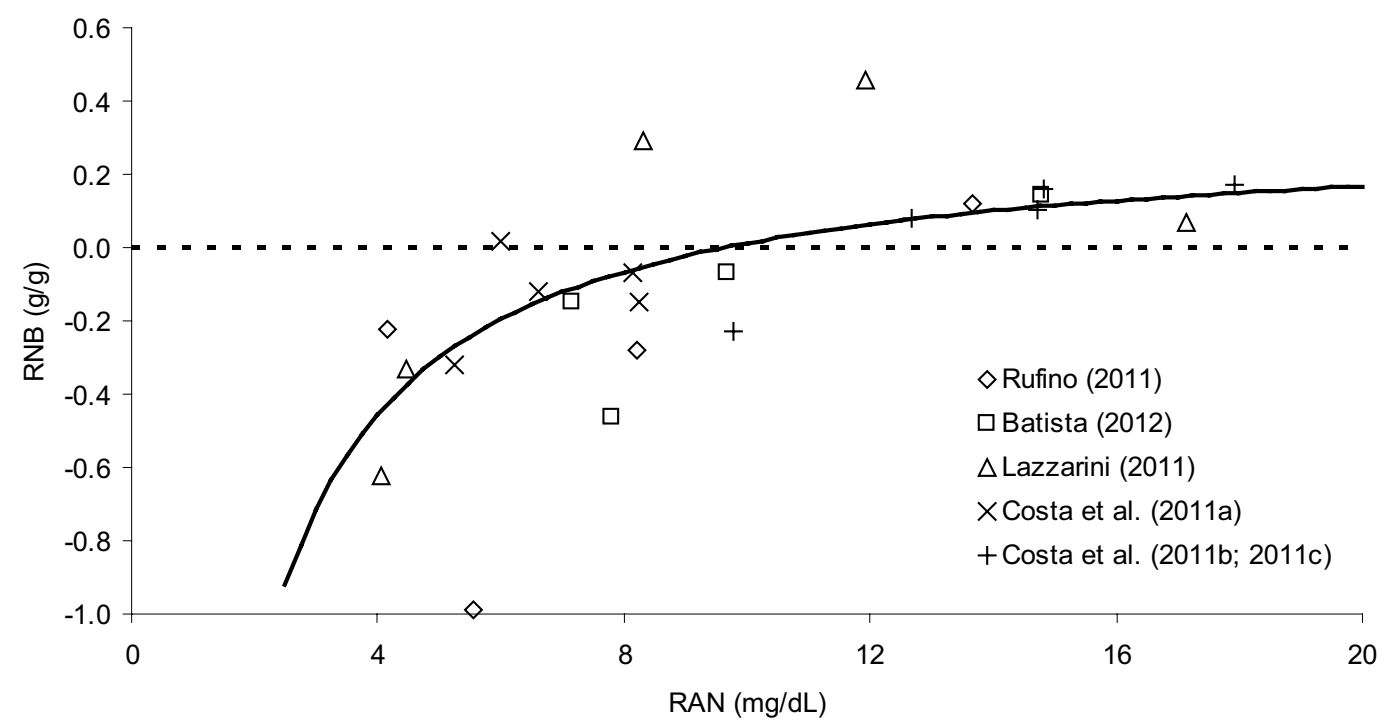

Source: Elaboration of the authors.

However, the intensity of urea transport through the rumen wall should not be viewed as a simple passive mechanism because it is a complex interactive mechanism between the microorganism and the host animal that is specifically regulated (WATERLOW, 2006). The rate of urea transfer from the blood to the rumen is regulated by the expression of epithelial and microbial ureases (CHALUPA et al., 1970; CHENG; WALLACE, 1979) and by the synthesis of urea transporters and aquaporines in the rumen epithelium (MARINI; VAN AMBURGH, 2003; MARINI et al., 2004; SIMMONS et al., 2009; CALSAMIGLIA et al., 2010; RØJEN et al., 2011). However, the exact association between the synthesis of urea transporters and aquaporines in the rumen wall and the regulation of urea transport from blood still remains to be established (CALSAMIGLIA et al., 2010).

Specifically, the ureolytic activity in the rumen epithelium is positively associated with urea transfer from the blood (CHALUPA et al.; 1970; CHENG; WALLACE, 1979; KENNEDY; CLARKE; MILLIGAN, 1981).
The RAN concentration plays a major role in the regulatory mechanisms of microbial and epithelial ureolytic activities (NRC, 1985; HUNTINGTON; ARQUIBEQUE, 2000; MARINI; VAN AMBURGH, 2003). The expression of urease by the bacteria living on the rumen epithelium is negatively regulated by the RAN concentration. Animals presenting a low RAN concentration could exhibit increased urea transfer from the blood to the rumen (BUNTING et al., 1989). Therefore, any increase or decrease in urea transfer mediated by bacterial urease should be indirectly and negatively regulated by the RAN concentration (CHENG; WALLACE, 1979).

It can be inferred that low RAN concentrations can increase the proportion of urea that is recycled to the rumen (HARMEYER; MARTENS, 1980; MARINI; VAN AMBURGH, 2003; MARINI et al., 2004; WICKERSHAM et al., 2008; MUSCHER et al., 2010; RØJEN; THEIL; KRISTENSEN, 2011). To some extent, that mechanism seems to be responsible for the negative nitrogen balance in the rumen of non-supplemented animals (Figures 9 and 
10). Thus, the rumen of a non-supplemented animal can increase the proportion of urea taken from arterial blood (RØJEN; THEIL; KRISTENSEN, 2011). According to Kennedy and Milligan (1978), the maximal urea transference to the rumen of cattle occurs at RAN concentrations of $5-8 \mathrm{mg} / \mathrm{dL}$. Therefore, supplementation with rumen-degradable nitrogenous compounds will increase the RAN concentration and, as a consequence, decrease the participation of recycled nitrogen in the RAN pool (NRC, 1985), causing a positive nitrogen balance in the rumen (Figure 9). In a recent meta-analytical approach on nitrogen metabolism with dairy cows,
Broderick et al. (2010) found that RAN was the best predictor for nitrogen balance in the rumen.

Increased ruminal demands for urea under low RAN concentrations were verified by Kennedy and Milligan (1978) and Marini and Van Amburgh (2003). The great nitrogen demand of the rumen is also indirectly supported by studies in which animals receive nitrogen supplementation in a postrumen site. In these animals, the nitrogen balance in the rumen became more negative, indicating that supplemental nitrogen was transferred to supply ruminal nitrogen demands, that means supporting microbial synthesis and growth (Figure 10).

Figure 10. Relative nitrogen balance in the rumen (RNB, $g$ N leaving the rumen $/ \mathrm{g} \mathrm{N}$ consumed) in cattle fed tropical forages according to different supplementation sites (control = without supplementation; $\mathrm{R}=$ supplementation with casein in the rumen; $\mathrm{A}=$ supplementation with casein in the abomasum; the protein supplied in the abomasum was not used to calculate the rumen nitrogen outflow as well as RNB).

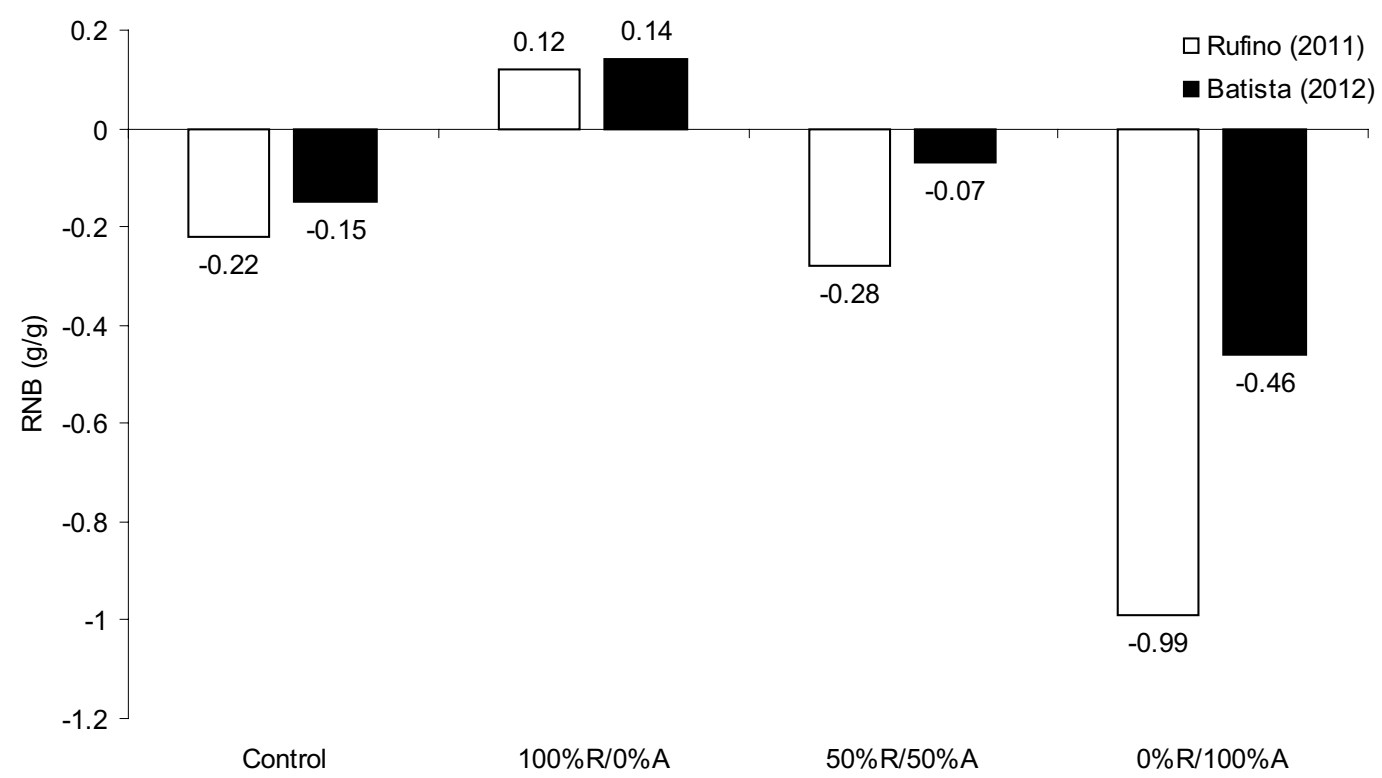

Source: Elaboration of the authors.

Assuming that the RAN concentration regulates urea transfer to the rumen, it could be stated that this mechanism would be significant only during the dry season because the lower nitrogen contents in the forage imply lower nitrogen availability in the rumen. However, in addition to the RAN concentration, the ruminal degradation of organic matter (OM) affects, in a direct and positive way, urea transfer to the rumen (KENNEDY; MILLIGAN, 1978; KENNEDY; CLARKE; MILLIGAN, 1981) and possibly reflects the increased microbial growth when forage is of better quality (DETMANN; PAULINO; VALADARES FILHO, 2010; LAZZARINI, 2011). 
To understand this statement, two experimental situations can be contrasted with each other. Those situations are based on the utilization of the same animals and pasture during sequential dry and rainy seasons and on diets with similar CP contents (Table 2). A lower RAN concentration occurred during the dry season. If the RAN concentration was the sole regulatory mechanism of urea transfer, then urea transfer would be greater during the dry season. However, in the rainy season, the amount of $\mathrm{OM}$ degraded in the rumen increased by $80 \%$ (Table 2 ), which would cause a significant increase in the amount of nitrogen required to sustain microbial growth. This result emphasizes that the rumen nitrogen demand would be more intense during the rainy season. According to Kennedy, Clarke and Milligan (1981), any increase in the amount of OM degraded in the rumen would be associated with a decrease in the concentration of blood urea nitrogen, in agreement with the results presented here (Table 2).

Table 2. Comparison between different experiments with regard crude protein in the diet $(\mathrm{CP}, \%$ of dry matter), concentration of rumen ammonia nitrogen (RAN, mg/ $\mathrm{dL}$ ), concentration of serum urea nitrogen ( $\mathrm{SUN}, \mathrm{mg} / \mathrm{dL}$ ), ruminal digestibility of crude protein (RDCP, \%), organic matter intake (OMI, $\mathrm{g} / \mathrm{kg}$ body weight), apparent ruminal digestibility of organic matter (RDOM, \%), and organic matter apparently digested in the rumen (OMDR, $\mathrm{g} / \mathrm{kg}$ body weight).

\begin{tabular}{ccc}
\hline \multirow{2}{*}{ Item } & \multicolumn{2}{c}{ Experiment $^{1}$} \\
\cline { 2 - 3 } & Dry season $^{2}$ & Rainy season $^{3}$ \\
\hline CP & 8.92 & 8.98 \\
RAN & $7.78(80 \%)$ & $9.77(100 \%)$ \\
SUN & 14.1 & 10.3 \\
RDCP & 1.21 & -22.6 \\
OMI & 16.10 & 21.44 \\
RDOM & 36.81 & 49.82 \\
OMDR & $5.93(100 \%)$ & $10.68(180 \%)$ \\
\hline
\end{tabular}

${ }^{1}$ The experiments during dry and rainy season were sequentially conducted using the same area and the same animals. ${ }^{2}$ The animals were grazing a pasture with $7.55 \% \mathrm{CP}$ and receiving $0.35 \mathrm{~g}$ of $\mathrm{CP} / \mathrm{kg}$ body weight as supplement. ${ }^{3}$ The animals were grazing a pasture with $8.98 \% \mathrm{CP}$.

Source: Elaboration of the authors from results of Figueiras et al. (2010) and Costa et al. (2011b; 2011c).
The body urea pool is homeostatically controlled to sustain some essential functions, including the conservation of nitrogen (VAN SOEST, 1994; MARINI; VAN AMBOURGH, 1993; MARINI et al., 2004). The liver synthesis of urea involves the assimilation of two nitrogen atoms, one from mitochondrial ammonia (through carbamylphosphate synthesis) and one from cytoplasmic aspartate (LINDSAY; REYNOLDS, 2005). The pools for mitochondrial and cytoplasm transamination are normally under equilibrium, and so the two nitrogen atoms of urea may come from ammonia or from amino acids by the reversible action of glutamate dehydrogenase. However, under a high urea flow or demand, the mitochondrial ammonia is not sufficient to supply both nitrogen atoms resulting in an increased utilization of amino acids for urea synthesis (PARKER et al., 1995).

The utilization of amino acids for urea synthesis could be increased when there is an increased occurrence of the urea cycle (LOBLEY et al., 1995) and could be associated with low nitrogen retention in the bodies of ruminants fed forage-based diets (PARKER et al., 1995). Marini and Van Amburgh (2003) reported that an improvement in nitrogen supply increased the liver synthesis of urea from dietary urea (which could indirectly indicate a decrease in the utilization of other sources for urea synthesis, such as amino acids).

The amino acids used for urea synthesis are derived from the blood pool of free amino acids (WATERLOW, 1999); the size of this pool is homeostatically regulated (VAN SOEST, 1994). Thus, considering an increased uptake of free amino acids by the liver, the homeostatic maintenance of the blood amino acid pool would be sustained by two different metabolic mechanisms: 1. utilization of the amino acids absorbed in the intestine (MP), which can decrease the rate of protein synthesis in the whole body; and 2. increasing the rate of myofibril protein breakdown (DETMANN; PAULINO; VALDARES FILHO, 2010; RUFINO, 2011). The first mechanism was previously discussed when the 
utilization of protein absorbed in the intestine (MP) caused a decrease in the rumen nitrogen balance, indirectly indicating an attempt to supply the rumen demand for nitrogen from MP (Figure 10). This type of amino acid utilization decreases the efficiency of conversion of MP into net protein (weight gain) (LAZZARINI, 2011). The second mechanism can be observed through increased 3-methylhistidine (3-MH) excretion when the RAN concentration became low (Figure 11). 3-MH is formed after the deposition of a histidine in the myofibril protein and cannot be used for new synthesis after the breakdown of muscle protein (WATERLOW, 2006). Thus, increased 3-MH excretion indicates an increased rate of myofibril protein mobilization. The sum of both mechanisms means that the fractional rate of muscle protein synthesis is reduced when RAN concentrations are low. In this way, an indirect and strong association between the RAN concentration and the efficiency of nitrogen utilization in the animal body can be established (Figure 12). Because the RAN concentration represents the nitrogen availability in the rumen, a positive association between the nitrogen balance in the rumen and the efficiency of nitrogen utilization was also established (Figure 13).

According to the adjusted function shown in Figure 12, the efficiency of nitrogen utilization in the animal body is maximized when the RAN concentration exceeds $16.6 \mathrm{mg} / \mathrm{dL}$ (Figure 12). However, it must be highlighted that the efficiency of nitrogen utilization was here interpreted using a asymptotic hyperbolic model (Figure 12). Negative effects of excessive nitrogen on intake and production were here described in the previous section. Thus, a continuous increasing in the RAN concentration below the limits here evaluated could not result in a stable efficiency. A recent work with dairy cows has pointed out that efficiency of nitrogen utilization decreases as $\mathrm{CP}$ and RDP contents are increase in the diet (HUHTANEN; HRISTOV, 2009) and it seems possible to occur with grazing beef cattle receiving excessive supplemental CP (or with very high RAN concentration).

Figure 11. Urinary excretion of 3-methylhistidine (3-MH) as a function of rumen ammonia nitrogen concentration (RAN) in cattle fed tropical forages $\left(\hat{Y}=1120.0 \times \mathrm{e}^{-0.8589 \times \mathrm{X}}+19.1657, \mathrm{~s}_{\mathrm{XY}}=5.88, \mathrm{n}=32\right.$; the urinary excretion of $3-\mathrm{MH}$ is directly associated with myofibril protein breakdown).

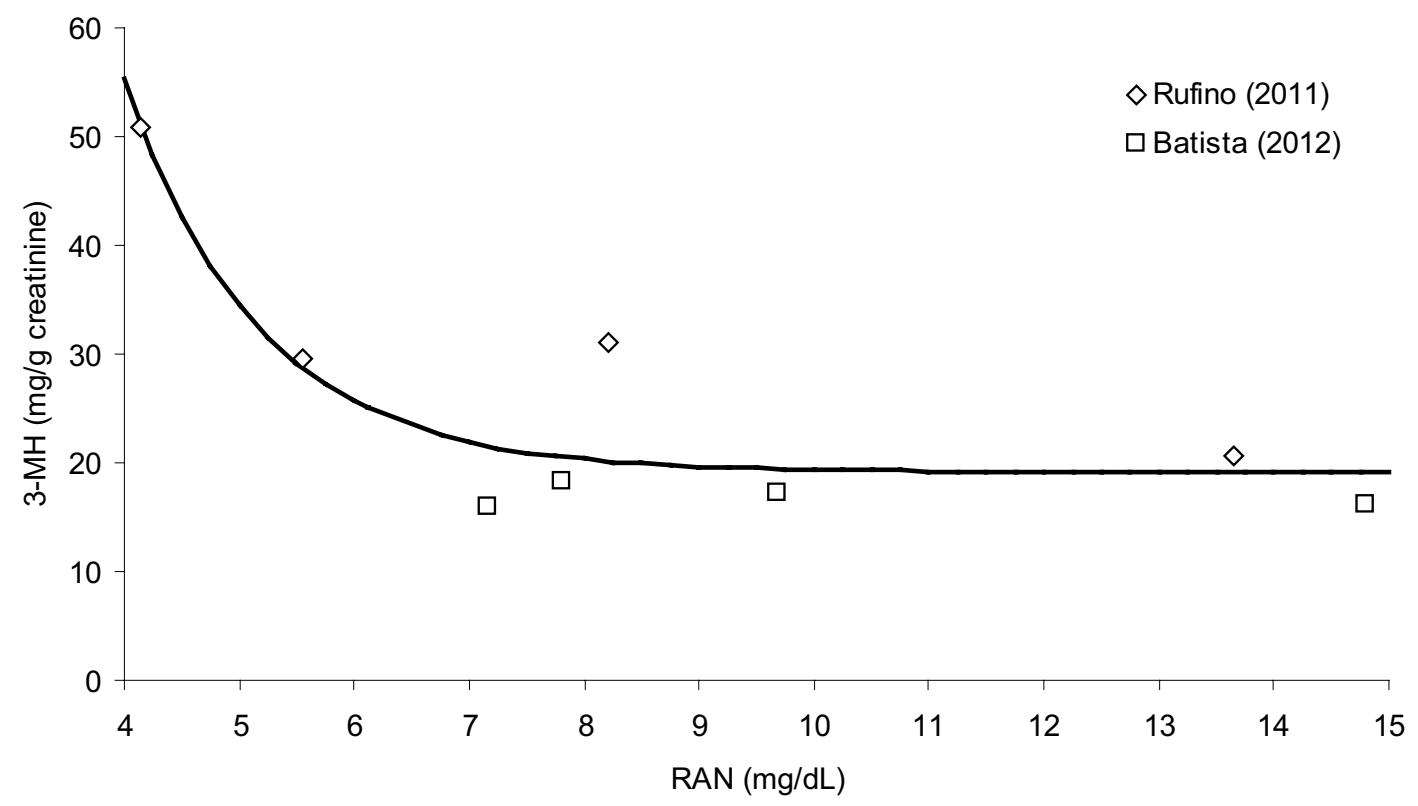

Source: Elaboration of the authors. 
Figure 12. Relative efficiency of nitrogen utilization (EFN, g N retained in the body/g $\mathrm{N}$ consumed) as a function of rumen ammonia nitrogen concentration (RAN) in cattle fed medium- to high-quality tropical forages $(\hat{\mathrm{Y}}=0.4309 \times$ $[1-(4.4068 / \mathrm{X})], \mathrm{s}_{\mathrm{XY}}=0.1082, \mathrm{n}=107$; using the asymptotic confidence interval of the plateau it is obtained that EFN is maximized at $\mathrm{RAN} \geq 16.60 \mathrm{mg} / \mathrm{dL})$.

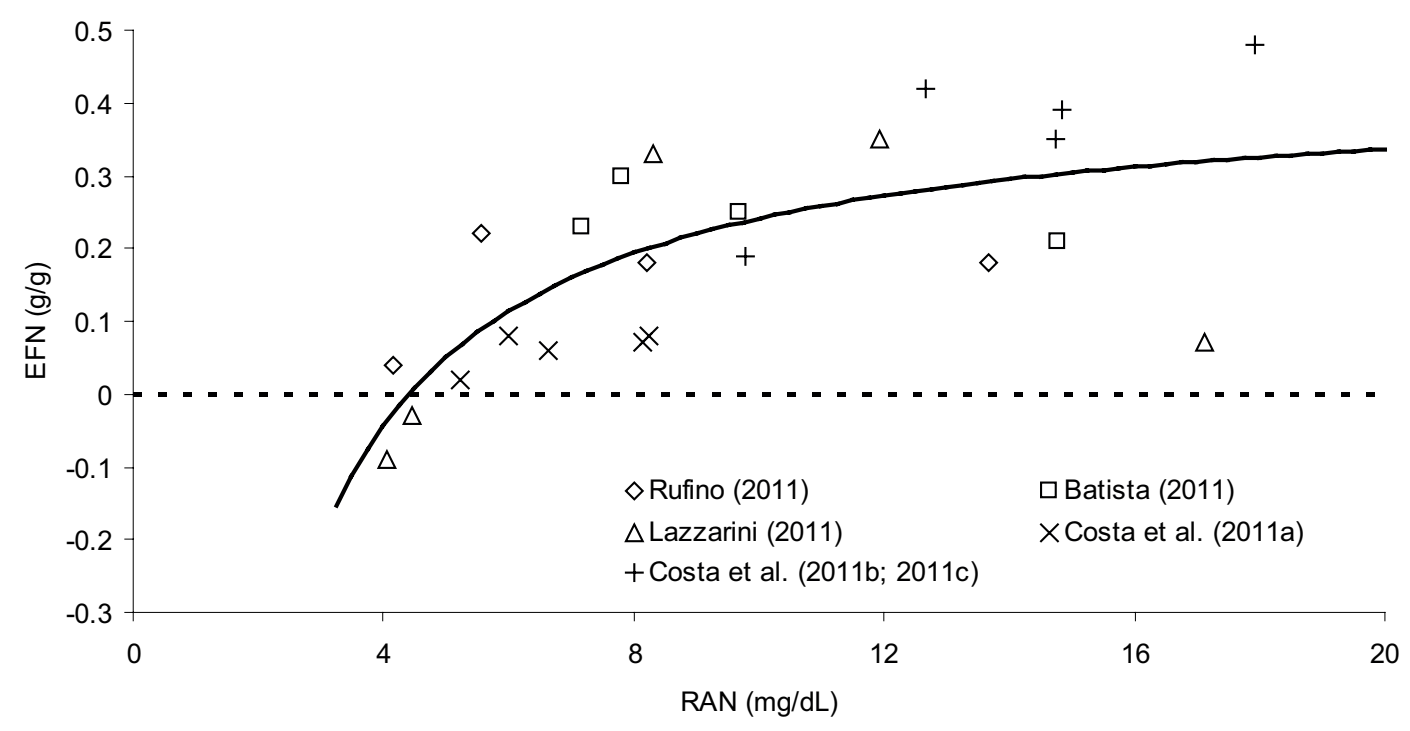

Source: Elaboration of the authors.

Figure 13. Relative efficiency of nitrogen utilization (EFN, g N retained in the body/g N consumed) as a function of relative nitrogen balance in the rumen (RNB, $g$ N leaving the rumen/g $\mathrm{N}$ consumed) in cattle fed medium- to highquality tropical forages $\left(\hat{\mathrm{Y}}=0.1955 \times \mathrm{e}^{1.8199 \times \mathrm{X}}, \mathrm{s}_{\mathrm{XY}}=0.1261, \mathrm{n}=107\right)$.

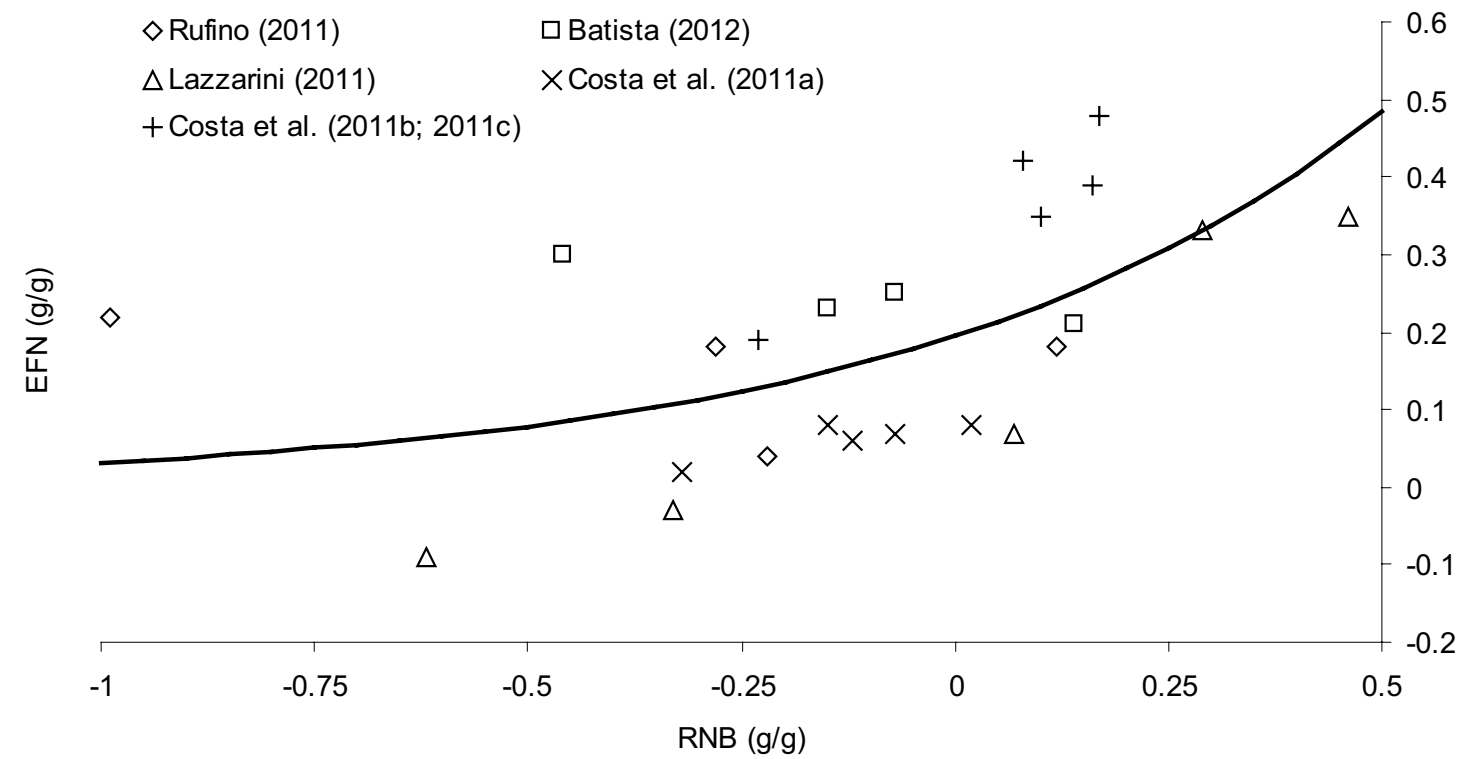

Source: Elaboration of the authors.

In summary, the first phase of nutritional to high-quality forages must be based on the supply planning (Figure 1) for animals grazing on medium- of rumen-degradable nitrogenous compounds to 
increase the RAN concentration up to $16 \mathrm{mg} / \mathrm{dL}$ (Figures 9 and 12). However, as in the dry season, some metabolic mechanisms of integration between energy and protein can potentiate nitrogen retention in the animal body (LAZZARINI, 2011; Figure 6), since that it does not occur any diet disequilibrium that can compromise the voluntary intake of forage. Although, further research is necessary to correctly define the optimal composition and amount of supplements to be offered for the different categories of animals grazing on medium- to high-quality tropical forages.

\section{Acknowledgments}

The authors wish to thank the CNPq, FAPEMIG and INCT Ciência Animal for the financial support. A special highlighting should be done to the Department of Agricultural Research for Northern Sweden at Swedish University of Agricultural Sciences.

\section{References}

ALLEN, M. S. Physical constraints on voluntary intake of forages by ruminants. Journal of Animal Science, Champaign, v. 74, n. 12, p. 3063-3075, 1996.

BATISTA, E. D. Suplementação protéica ruminal el ou abomasal em bovinos em bovinos alimentados com forragem tropical de alta qualidade. 2012. Dissertação (Mestrado em Zootecnia) - Universidade Federal de Viçosa, Viçosa.

BRODERICK, G. A.; HUHTANEN, P.; AHVENJÄRVI, S.; REYNAL, S. M.; SHINGFIELD, K. J. Quantifying ruminal nitrogen metabolism using the omasal sampling technique in cattle - a meta-analysis. Journal of Dairy Science, Champaign, v. 93, n. 7, p. 3216-3230, 2010.

BUNTING, L. D.; BOLING, J. A.; MACKOWN, C. T.; DAVENPORT, G. M. Effect of dietary protein level on nitrogen metabolism in the growing bovine: II diffusion into and utilization of endogenous urea nitrogen in the rumen. Journal of Animal Science, Champaign, v. 67, n. 3, p. 820-826, 1989.

CALSAMIGLIA, S.; FERRET, A.; REYNOLDS, C. K.; KRISTENSEN, N. B.; VAN VUUREN, A. M. Strategies for optimizing nitrogen use by ruminants. Animal,
Cambridge, v. 4, n. 7, p. 1184-1196, 2010.

CARVALHO, I. P. C.; DETMANN, E.; MANTOVANI, H. C.; PAULINO, M. F.; VALADARES FILHO, S. C.; COSTA, V. A. C.; GOMES, D. I. In vitro growth and antimicrobial activity of lactic acid bacteria from rumen fluid according to energy or nitrogen source. Revista Brasileira de Zootecnia, Viçosa, v. 40, n. 6, p. 12601265, 2011.

CHALUPA, W. C.; CLARK, J.; OPLIGER, P.; LAVKER, R. Ammonia metabolism in rumen bacteria and mucosa from sheep fed soy protein or urea. Journal of Nutrition, Bethesda, v. 100, n. 2, p. 161-169, 1970.

CHENG, K. J.; WALLACE R. J. The mechanism of passage of endogenous urea through the rumen wall and the role of ureolytic epithelial bacteria in the urea flux. British Journal of Nutrition, Cambridge, v. 42, n. 3, p. 553-557, 1979.

COSTA, D. F. A. Respostas de bovinos de corte à suplementação energética em pastos de capim-marandu submetidos a intensidades de pastejo rotativo durante o verão. 2007. Dissertação (Mestrado em Ciência Animal e Pastagens) - Universidade de São Paulo/Escola Superior de Agricultura Luiz de Queiroz, Piracicaba.

COSTA, V. A. C.; DETMANN, E.; PAULINO, M. F.; VALADARES FILHO, S. C.; CARVALHO, I. P. C.; MONTEIRO, L. P. Consumo e digestibilidade em bovinos em pastejo durante o período das águas sob suplementação com fontes de compostos nitrogenados e de carboidratos. Revista Brasileira de Zootecnia, Viçosa, v. 40, n. 8, p. 1788-1798, 2011 a.

COSTA, V. A. C.; DETMANN, E.; PAULINO, M. F.; VALADARES FILHO, S. C.; HENRIQHES, L. T.; CARVALHO, I. P. C.; VALENTE, T. N. P. Consumo e dinâmica ruminal da fibra em detergente neutro em bovinos em pastejo no período das águas recebendo suplementação com nitrogênio não-proteico e/ou proteína verdadeira. Revista Brasileira de Zootecnia, Viçosa, v. 40, n. 12, p. 2805-2814, 2011 b.

Digestibilidade total e parcial e balanço nitrogenado em bovinos em pastejo no período das águas recebendo suplementos com nitrogênio não-proteico e/ ou proteína verdadeira. Revista Brasileira de Zootecnia, Viçosa, v. 40, n. 12, p. 2815-2826, 2011c.

COSTA, V. A. C.; DETMANN, E.; VALADARES FILHO, S. C.; PAULINO, M. F.; HENRIQUES, L. T.; MANTOVANI, H. C. Degradação in vitro da fibra em detergente neutro de forragem tropical de baixa qualidade em função de suplementação com proteína e/ ou carboidratos. Revista Brasileira de Zootecnia, Viçosa, v. 37, n. 3, p. 494-503, 2008. 
Degradação in vitro da fibra em detergente neutro de forragem tropical de alta qualidade em função da suplementação com proteína e/ou carboidratos. Revista Brasileira de Zootecnia, Viçosa, v. 38, n. 9, p. 1803-1811, 2009.

DETMANN, E. Fibra na nutrição de novilhas leiteiras. In: PEREIRA, E. S.; PIMENTEL, P. G.; QUEIROZ, A. C.; MIZUBUTI, I. Y. (Ed.) Novilhas leiteiras. Fortaleza: Graphiti, 2010. p. 253-302.

DETMANN, E.; PAULINO, M. F.; MANTOVANI, H. C.; VALADARES FILHO, S. C.; SAMPAIO, C. B.; SOUZA, M. A.; LAZZARINI, I.; DETMANN, K. S. C. Parameterization of ruminal fibre degradation in lowquality tropical forage using Michaelis-Menten kinetics. Livestock Science, Amsterdam, v. 126, n. 1-3, p. 136-146, 2009.

DETMANN, E.; PAULINO, M. F.; VALADARES FILHO, S. C. Avaliação de alimentos ou de dietas? Uma abordagem conceitual. In: SIMPÓSIO DE PRODUÇÃO DE GADO DE CORTE, 6., 2008, Viçosa. Anais... Viçosa: Departamento de Zootecnia/UFV, 2008. p. 21-52

Otimização do uso de recursos forrageiros basais. In: SIMPÓSIO DE PRODUÇÃO DE GADO DE CORTE, 7., 2010, Viçosa. Anais... Viçosa: Departamento de Zootecnia/UFV, 2010. p. 191-240.

DETMANN, E.; PAULINO, M. F.; VALADARES FILHO, S. C.; LANA, R. P. Fatores controladores de consumo em suplementos múltiplos fornecidos ad libitum para bovinos manejados a pasto. Cadernos Técnicos de Veterinária e Zootecnia, Belo Horizonte, v. 55, p. 73-93, 2007.

DETMANN, E.; PAULINO, M. F.; ZERVOUDAKIS, J. T.; VALADARES FILHO, S. C.; LANA, R. P.; QUEIROZ, D. S. Suplementação de novilhos mestiços durante a época das águas: parâmetros ingestivos e digestivos. Revista Brasileira de Zootecnia, Viçosa, v. 30, n. 4, p. 1340-1349, 2001.

DETMANN, E.; QUEIROZ, A. C.; CECON, P. R.; ZERVOUDAKIS, J. T.; PAULINO, M. F.; VALADARES FILHO, S. C.; CABRAL, L. S.; LANA, R. P. Consumo de fibra em detergente neutro por bovinos em confinamento. Revista Brasileira de Zootecnia, Viçosa, v. 32, n. 6s, p. 1763-1777, 2003.

DETMANN, E.; QUEIROZ, A. C.; ZORZI, K.; MANTOVANI, H. C.; BAYÃO, G. F. V.; GOMES, M. P. C. Degradação in vitro da fibra em detergente neutro de forragem tropical de baixa qualidade em função da suplementação com proteína verdadeira e/ou nitrogênio não-proteico. Revista Brasileira de Zootecnia, Viçosa, v. 40, n. 6, p. 1272-1279, 2011.
EL-SHAZLY, K.; DEHORITY, B. A.; JOHNSON, R. $\mathrm{R}$. Effect of starch on the digestion of cellulose in vitro and in vivo on rumen microorganisms. Journal of Animal Science, Champaign, v. 20, n. 2, p. 268-276, 1961.

FIGUEIRAS, J. F.; DETMANN, E.; PAULINO, M. F.; VALENTE, T. N. P.; VALADARES FILHO, S. C.; LAZZARINI, I. Intake and digestibility in cattle under grazing during dry season supplemented with nitrogenous compounds. Revista Brasileira de Zootecnia, Viçosa, v. 39, n. 6, p. 1303-1312, 2010.

FIGUEIREDO, D. M.; PAULINO, M. F.; SALES, M. F. L.; VALADARES FILHO, S. C.; DETMANN, E.; BARROS, L. V. Levels of ground corn supplied to beef heifers at pasture during the rainy season: productive performance, intake, digestibility and microbial efficiency. Revista Brasileira de Zootecnia, Viçosa, v. 40, n. 11, p. 2523-2531, 2011.

FORBES, J. M. The multifactorial nature of food intake control. Journal of Animal Science, Champaign, v. 81, p. E139-E144, 2003. Eletronic Supplement 2.

Voluntary food intake and diet selection in farm animals. London: CAB International, 1995. 432 p.

HAFLEY, J. L.; ANDERSON, B. E.; KLOPFENSTEIN, T. J. Supplementation of growing cattle grazing warm-season grass with proteins of various ruminal degradabilities. Journal of Animal Science, Champaign, v. 71, n. 2, p. 522-529, 1993.

HARMEYER, J.; MARTENS, H. Aspects of urea metabolism in ruminants with reference to the goat. Journal of Dairy Science, Champaign, v. 63, n. 10, p. 1707-1728, 1980.

HENNESSY, D. W.; NOLAN, J. V. Nitrogen kinetics in cattle fed a mature subtropical grass hay with and without protein meal supplementation. Australian Journal of Agricultural Research, Collingwood, v. 39, n. 6, p. 11351150, 1988.

HOOVER, W. H. Chemical factors involved in ruminal fiber digestion. Journal of Dairy Science, Champaign, v. 69, n. 10, p. 2755-2766, 1986.

HUHTANEN, P. Associative effects of feeds in ruminants. Norwegian Journal of Agricultural Sciences, Ås, v. 5, n. 1, p. 37-57, 1991.

HUHTANEN, P. New developments in the prediction of intake of silage based diets. In: INTERNATIONAL SILAGE CONFERENCE, 13., 2002, Auchincruive. Anais... Auchincruive: Scottish Agricultural College, 2002. p. 236-251.

HUHTANEN, P.; HRISTOV, A. N. A meta-analysis of the effects of dietary protein concentration and degradability 
on milk protein yield and milk $\mathrm{N}$ efficiency in dairy cows. Journal of Dairy Science, Champaign, v. 92, n. 7, p. 3222-3232, 2009.

HUHTANEN, P.; RINNE, M.; NOUSIAINEN, J. Evaluation of the factors affecting silage intake of dairy cows: a revision of the relative silage dry matter intake index. Animal, Cambridge, v. 1, n. 5, p. 758-770, 2007.

HUNTINGTON, G. B.; ARCHIBEQUE, S. L. Practical aspects of urea and ammonia metabolism in ruminants. Journal of Animal Science, Champaign, v. 77, p. 1-11, 2000.

ILLIUS, A. W.; JESSOP, N. S. Metabolic constraints on voluntary intake in ruminants. Journal of Animal Science, Champaign, v. 74, n. 12, p. 3052-3062, 1996.

KENNEDY, P. M.; CLARKE, R. T. J.; MILLIGAN, L. P. Influences of dietary sucrose and urea on transfer of endogenous urea to the rumen of sheep and numbers of epithelial bacteria. British Journal of Nutrition, Cambridge, v. 46, n. 3, p. 533-541, 1981.

KENNEDY, P. M.; MILLIGAN, L. P. The effects of dietary sucrose and the concentrations of plasma urea and rumen ammonia on the degradation of urea in the gastrointestinal tract of cattle. British Journal of Nutrition, Cambridge, v. 43, n. 1, p. 125-140, 1978.

LAZZARINI, I. Desempenho nutricional de bovinos em pastejo durante os períodos de seca e águas suplementados com compostos nitrogenados elou amido. 2011. Tese (Doutorado em Zootecnia) - Universidade Federal de Viçosa, Viçosa.

LAZZARINI, I.; DETMANN, E.; SAMPAIO, C. B.; PAULINO, M. F.; VALADARES FILHO, S. C.; SOUZA, M. A.; OLIVEIRA, F. A. Dinâmicas de trânsito e degradação da fibra em detergente neutro em bovinos alimentados com forragem tropical de baixa qualidade e compostos nitrogenados. Arquivo Brasileiro de Medicina Veterinária e Zootecnia, Belo Horizonte, v. 61, n. 3, p. 635-647, 2009a.

A. Intake and digestibility in cattle fed lowquality tropical forage and supplemented with nitrogenous compounds. Revista Brasileira de Zootecnia, Viçosa, v. 38, n. 10, p. 2021-2030, 2009b.

LENG, R. A. Factors affecting the utilization of "poorquality" forages by ruminants particularly under tropical conditions. Nutrition Research Reviews, Cambridge, v. 3, n. 1, p. 277-303, 1990.

LINDSAY, D. B.; REYNOLDS, C. K. Metabolism of the portal-drained viscera and liver. In: DIJKSTRA, J.; FORBES, J. M.; FRANCE, J. (Ed.). Quantitative aspects of ruminant digestion and metabolism. 2. ed. Wallingford: CABI Publishing, 2005. p. 373-398.
LOBLEY, G. E.; CONNELL, A.; LOMAX, M. A.; BROWN, D. S.; MILNE, E.; CALDER, A. G.; FARNINGHAM, D. A. H. Hepatic detoxification of ammonia in the ovine liver: possible consequences for amino acid catabolism. British Journal of Nutrition, Cambridge, v. 73, n. 5, p. 667-685, 1995

MARINI, J. C.; KLEIN, J. D.; SANDS, J. M.; VAN AMBURGH, M. E. Effect of nitrogen intake on nitrogen recycling and urea transporters abundance in lambs. Journal of Animal Science, Champaign, v. 82, n. 4, p. 1157-1164, 2004.

MARINI, J. C.; VAN AMBURGH, M. E. Nitrogen metabolism and recycling in Holstein heifers. Journal of Animal Science, Champaign, v. 81, n. 2, p. 545-552, 2003.

McALLAN, A. B.; SMITH, R. H. Factors influencing the digestion of dietary carbohydrates between mouth and abomasum. British Journal of Nutrition, Cambridge, v. 50, n. 2, p. 444-454, 1983.

MERTENS, D. R. Rate and extent of digestion. In: FORBES, J. M.; FRANCE, J. (Ed.). Quantitative aspects of ruminant digestion and metabolism. Wallingford: CAB Publishing, 1993. p. 13-5.

MORAES, E. H. B. K.; PAULINO, M. F.; ZERVOUDAKIS, J. T.; DETMANN, E.; VALADARES FILHO, S. C.; VALADARES, R. F. D.; MORAES, K. A. K. Níveis de proteína em suplementos para novilhos mestiços em pastejo durante o período de transição seca/ águas. Revista Brasileira de Zootecnia, Viçosa, v. 35, n. 5, p. 2135-2143, 2006.

MOULD, F. L.; ØRSKOV, E. R.; MANN, S. O. Associative effects of mixed feeds. I. Effects of type and level of supplementation and the influence of the rumen fluid $\mathrm{pH}$ on cellulolysis in vivo and dry matter digestion of various roughages. Animal Feed Science and Technology, Amsterdam, v. 10, n. 1, p. 15-30, 1983.

MUSCHER, A. S.; SCHRÖDER, B.; BREVES, G.; HUBER, K. Dietary nitrogen reduction enhances urea transport across goat rumen epithelium. Journal of Animal Science, Champaign, v. 88, n. 10, p. 3390-3398, 2010.

NATIONAL RESEARCH COUNCIL - NRC. Ruminant nitrogen usage. Washington, DC: Academic Press, 1985. $119 \mathrm{p}$.

PARKER, D. S.; LOMAX, M. A.; SEAL, C. J.; WILTON, J. C. Metabolic implications of ammonia production in the ruminant. Proceedings of the Nutrition Society, Cambridge, v. 54, n. 2, p. 549-563, 1995.

PAULINO, M. F.; DETMANN, E.; VALENTE, E. E. L.; BARROS, L. V. Nutrição de bovinos em pastejo. 
In: SIMPÓSIO SOBRE MANEJO ESTRATÉGICO DA PASTAGEM, 4., 2008, Viçosa. Anais... Viçosa: Departamento de Zootecnia/UFV, 2008. p. 131-169.

PAULINO, M. F.; MORAES, E. H. B. K.; ZERVOUDAKIS, J. T.; ALEXANDRINO, E.; FIGUEIREDO, D. M. Terminação de novilhos mestiços leiteiros sob pastejo, no período das águas, recebendo suplementação com soja. Revista Brasileira de Zootecnia, Viçosa, v. 35, n. 1, p. 154-158, 2006.

POPPI, D. P.; McLENNAN, S. R. Protein and energy utilization by ruminants at pasture. Journal of Animal Science, Champaign, v. 73, n. 1, p. 278-290, 1995.

PORTO, M. O. Suplementos múltiplos para bovinos de corte nas fases de cria, recria e terminação em pastagens de Brachiaria decumbens. 2009. Tese (Doutorado em Zootecnia) - Universidade Federal de Viçosa, Viçosa.

RAMALHO, T. R. A. Suplementação protéica ou energética para bovinos recriados em pastagens tropicais. 2006. Dissertação (Mestrado em Ciência Animal e Pastagens) - Universidade de São Paulo/Escola Superior de Agricultura Luiz de Queiroz, Piracicaba.

RØJEN, B. A.; THEIL, P. K.; KRISTENSEN, N. B. Effects of nitrogen-supply on inter-organ fluxes of urea- $\mathrm{N}$ and renal urea-N kinetics in lactating cows. Journal of Dairy Science, Champaign, v. 94, n. 5, p. 2532-2544, 2011.

RØJEN, B.A.; POULSEN, S. B.; THEIL, P. K.; FENTON, R. A.; KRISTENSEN, N. B. Effects of dietary nitrogen concentration on messenger RNA expression and protein abundance of urea transporter-B and aquaporins in ruminal papillae from lactating Holstein cows. Journal of Dairy Science, Champaign, v. 94, n. 5, p. 2587-2591, 2011.

RUFINO, L. M. A. Suplementação nitrogenada ruminal elou abomasal em bovinos alimentados com forragem tropical. 2011. Dissertação (Mestrado em Zootecnia) Universidade Federal de Viçosa, Viçosa.

RUSSELL, J. B. Rumen microbiology and its role in ruminant nutrition. Ithaca: James B. Russell, 2002. 119 p.

SAMPAIO, C. B.; DETMANN, E.; LAZZARINI, I.; SOUZA, M. A.; PAULINO, M. F.; VALADARES FILHO, S. C. Rumen dynamics of neutral detergent fiber in cattle fed low-quality tropical forage and supplemented with nitrogenous compounds. Revista Brasileira de Zootecnia, Viçosa, v. 38, n. 3, p. 560-569, 2009.

SAMPAIO, C. B.; DETMANN, E.; PAULINO, M. F.; VALADARES FILHO, S. C.; SOUZA, M. A.; LAZZARINI, I.; PAULINO, P. V. R.; QUEIROZ, A. C. Intake and digestibility in cattle fed low-quality tropical forage and supplemented with nitrogenous compounds. Tropical Animal Health and Production, Amsterdam, v. 42, n. 7, p. 1471-1479, 2010.

SIEBERT, B. D.; KENNEDY, P. M. The utilization of spear grass (Heteropogon contortus). I.Factors limiting intake and utilization by cattle and sheep. Australian Journal of Agricultural Research, Collingwood, v. 23, n. 1, p. 35-44, 1972.

SIMMONS, N. L.; CHAUDHRY, A. S.; GRAHAM, E. S.; SCRIVEN, E. S.; HISTLETHWAITE, C. P.; SMITH, C. P.; STEWART, G. S. Dietary regulation of ruminal bUT-B urea transporter expression and localization. Journal of Animal Science, Champaign, v. 87, n. 10, p. 3288-3299, 2009.

SOUZA, M. A.; DETMANN, E.; PAULINO, M. F.; SAMPAIO, C. B.; LAZZARINI, I.; VALADARES FILHO, S. C. Intake, digestibility, and rumen dynamics of neutral detergent fibre in cattle fed low-quality tropical forage and supplemented with nitrogen and/or starch. Tropical Animal Health and Production, Amsterdam, v. 42, n. 6, p. 1299-1310, 2010.

STROBEL, H. J.; RUSSELL, J. B. Effect of $\mathrm{pH}$ and energy spilling on bacterial protein synthesis by carbohydrate-limited cultures of mixed rumen bacteria. Journal of Dairy Science, Champaign, v. 69, n. 11, p. 2941-2947, 1986.

VALADARES FILHO, S. C.; MARCONDES, M. I.; CHIZZOTTI, M. L.; PAULINO, P. V. R. (Ed.). Nutrient requirements of zebu beef cattle BR-CORTE. 2. ed. Visconde do Rio Branco: Suprema, 2010. 185 p.

VAN SOEST, P. J. Nutritional ecology of the ruminant. 2. ed. Ithaca: Cornell University Press, 1994. 476 p.

VISEK, W. L. Ammonia: its effects on biological systems, metabolic hormones, and reproduction. Journal of Dairy Science, Champaign, v. 67, n. 3, p. 481-498, 1984.

WALDO, D. R.; SMITH, L. W.; COX, E. L. Model of cellulose disappearance from the rumen. Journal of Dairy Science, Champaign, v. 55, n. 1, p. 125-129, 1972.

WATERLOW, J. C. Protein turnover. 2. ed. Wallingford: CABI Publishing, 2006. 313 p.

WATERLOW, J. C. The mysteries of nitrogen balance. Nutrition Research Reviews, v. 12, n. 1, p. 25-54, 1999.

WICKERSHAM, T. A.; TITGEMEYER, E. C.; COCHRAN, R. C.; WICKERSHAM, E. E.; GNAD, D. P. Effect of rumen-degradable intake protein supplementation on urea kinetics and microbial use of recycled urea in steers consuming low-quality forage. Journal of Animal Science, Champaign, v. 86, n. 11, p. 3079-3088, 2008. 
ZERVOUDAKIS, J. T. Suplementos múltiplos de auto controle de consumo e freqüência de suplementação, na recria de novilhos durante os periodos das águas e transição águas-secas. 2003. Tese (Doutorado em Zootecnia) - Universidade Federal de Viçosa, Viçosa.

ZERVOUDAKIS, J. T.; PAULINO, M. F.; CABRAL, L. S.; DETMANN, E.; VALADARES FILHO, S. C.; MORAES, E. H. B. K. Suplementos múltiplos de auto controle de consumo na recria de novilhos no período das águas. Ciência e Agrotecnologia, Lavras, v. 32, n. 6, p. 1968-1973, 2008.
ZERVOUDAKIS, J. T.; PAULINO, M. F.; DETMANN, E.; VALADARES FILHO, S. C.; LANA, R. P.; CECON, P. R. Desempenho de novilhas mestiças e parâmetros ruminais em novilhos, suplementados durante o período das águas. Revista Brasileira de Zootecnia, Viçosa, v. 31, n. 2s, p. 1050-1058, 2002. 